\title{
The Intangibles Song in Takeover Announcements: Good Tempo, Hollow Tune
}

\author{
Zoran M. Filipović and Alexander F. Wagner*
}

January 13, 2019

\begin{abstract}
Mergers and acquisitions are often motivated by the intention of creating extra value from intangible assets. We develop a novel word list of intangibles and apply it to the takeover announcements from 2002 to 2016 with a U.S. domiciled bidder. Deals presented with more "intangibles talk" in takeover announcements complete more quickly (and more frequently). However, the value of these deals to the acquirer is questionable: One standard deviation more in intangibles talk results in 0.45 percentage points lower abnormal announcement returns of bidders. We find little support for agency problems driving these results. Instead, an analysis of payment mode choices and of insider trades suggests that intangibles talk reflects managerial overoptimism. Overall, takeover announcements can be an important source of information regarding the quality of deals.
\end{abstract}

JEL Classification: G14, G34, G41

Keywords: Corporate announcements, intangible assets, intangibles talk, mergers and acquisitions, takeovers, textual analysis

${ }^{*}$ Filipović: Swiss Finance Institute, University of Lugano; zoran.filipovic@usi.ch. Wagner: Swiss Finance Institute, University of Zurich; CEPR; ECGI; alexander.wagner@bf .uzh.ch. François Degeorge, Rita Gunn, Micah Officer, Joshua White, and Richard Zeckhauser have provided very helpful comments. Richard Zeckhauser deserves special recognition for the title suggestion. We also thank seminar participants at the SFI Research Days, the Tokyo Institute of Technology, and the University of St. Gallen for comments. Our thanks go to Ivan Petzev for excellent research assistance. - The authors declare that they have no relevant or material financial interests that relate to the research described in this paper. 


\section{Introduction}

On July 20, 2011, Minnesota-based Ecolab Inc., a cleaning and sanitizing products producer, announced an acquisition of Nalco Holding Co., which makes chemicals used in industrial water treatment, energy and air applications. The transaction was valued at $\$ 8.1$ billion, inclusive of \$2.7 billion in Nalco net debt. As the key assets relevant for the deal, Ecolab's management listed, in the acquisition announcement, concepts such as innovation, processes, customers, markets, technology know-how, team and corporate culture. Ecolab's CEO is cited as stressing the importance of Nalco's expertise, services, efficiency, and market. ${ }^{1}$ This storyline was also picked up by the business press. ${ }^{2}$ In short, Ecolab tried hard to convince investors that Nalco is rich in intangible assets. However, investors were not convinced. The Ecolab stock price sharply fell and closed at $\$ 51.31$ on the announcement day, a drop of $7.4 \%$ from the previous day's closing price. This is substantially larger than the median bidder price reaction to acquisitions of public chemicals companies over the 2002 to 2016 period, which was $-1.3 \%$. Ecolab's share price recovered mildly the following day, but then drifted down further to end the 10-day period after the announcement at $\$ 49.53$, a fall of $10.6 \%$. Despite the negative market reaction, the deal was completed and Ecolab acquired Nalco.

This paper studies whether this pattern - even if an extreme case - is typical, that is, whether a seemingly strong use of "intangibles talk" in a takeover announcement indeed usually goes hand-in-hand with a negative (abnormal) investor reaction to the announcement. We find that it does. Further tests reveal that this relation is likely due to managerial overconfidence about deal quality. Agency issues (such as private benefits of managing a larger company) seem to play a far less pronounced role. Overall, our paper provides new evidence of the role of corporate communication and managerial motivations in corporate transactions.

Our study is motivated by the great importance of takeovers and the rising relevance of intangible assets. Takeovers are major corporate actions; they significantly impact the fu-

\footnotetext{
${ }^{1}$ Douglas M. Baker, Jr., Ecolab's Chief Executive Officer commented on the target, saying "Nalco is the global leader with deep expertise in programs and services to enhance water process efficiency, extend asset life, and improve their customers' end products. Nalco's water and oil and gas services end markets in particular represent excellent long term growth potential as the world deals with the quality, cost and availability of those key natural resources. Further, its geographic exposure to high-growth emerging markets offers terrific future potential for the combined companies." - https ://www . sec.gov/Archives/edgar/data/31462/ 000104746911006458/a2204877zex-99_1.htm

2 “We've long admired Nalco's capabilities, know-how and management team for years," said Ecolab Chief Executive Doug Baker in an interview. - The Wall Street Journal, July 20, 2011.
} 
ture of the acquiring company. Takeover announcements attract keen attention of investors and typically cause a considerable change in the current stock price. The literature documents a sizable variation in abnormal stock returns around the announcement date that ranges from rather negative to highly positive returns depending predictably on target and deal characteristics (see Moeller et al., 2004, 2007; Bargeron et al., 2008; Betton et al., 2008; Savor and Lu, 2009; Officer et al., 2009; Schneider and Spalt, 2017). While the positive market reaction causes no controversy, negative returns have triggered a wide debate. Two major explanations have evolved. The first explanation relies on the agency theory of Jensen and Meckling (1976) and attributes negative returns to distorted managerial objectives (see Jensen, 1986; Morck et al., 1990; Grinstein and Hribar, 2004), such as "empire building" and other private benefits. The second explanation draws on managerial behavioral biases, in particular overoptimism and overconfidence (see Roll, 1986; Malmendier and Tate, 2008; Ferris et al., 2013). Given the overall importance of takeovers and the scale of their impact on stock prices, it is crucial to understand whether takeover announcement content delivers valuable information to investors and whether it potentially discloses the genuine objective of the deal.

A successful acquisition requires a plausible valuation of the deal - but such valuations are arguably particularly challenging in the presence of intangible assets. Intriguingly, Lev (2012) documents a decline of 50\% in the ability of accounting data to explain share price differences across companies over 1975-2006. Casual observation also suggests that acquirers often refer to intangible assets in takeover announcements. This paper analyzes what market participants can and do infer from this intangibles talk. Are frequent references to intangibles just inconsequential managerial guff? Or do such references indeed reveal something about the deal over and above other observables?

To conduct a systematic analysis, we begin by developing a word list to measure the extent of intangibles talk on takeover announcements. Drawing on the strategy and business literature (Hall, 1992; Lev, 2005, 2012), we compile a dictionary of 213 words that indicate intangible assets. For example, each of the words highlighted in Ecolab's takeover announcement above is on that list. "Intangibles talk" then is the frequency of words associated with intangible assets.

Between 2002 and 2016, the median (average) U.S. takeover announcement contains about $2.3 \%(2.4 \%)$ words that are closely related to intangible assets, though there is substan- 
tial variation in that frequency across announcements. That variability enables this analysis. Ecolab's announcement has $2.3 \%$, what is considerably larger than the median of $1.3 \%$ for acquisitions of public targets that operate in the chemicals industry.

The main determinants of intangibles talk are the target industry, relative size of bidder and target, and public/private status. Intangibles talk is also related to the size of the bidder's intangible capital (measured in different ways), but this relation vanishes once one controls for industry fixed effects. Interestingly, the target's intangible capital (available in the subsample of publicly listed targets) is uncorrelated with intangibles talk. Managerial skill and background are not systematically related to intangibles talk.

Next, we examine whether bidders that talk more about intangible assets are faster and more likely to complete the deal. We find that they are: The time between the announcement and the effective date of the acquisition is shorter for deals announced with more intangibles talk, and these deals are more likely to complete. This result holds controlling for many deal characteristics. Thus, managers using intangibles talk in announcements seem particularly determined to see through the announced deal.

It is possible that managers refer more frequently to intangibles when they are disclosing advantageous private information regarding the target intangible capital, rather than merely repeating the visible. It would then be understandable that managers are keen to complete the deal. The data reject this idea. On average, the market reacts negatively to intangibles talk in the takeover announcements. One standard deviation more intangibles talk results in 0.45 percentage points lower abnormal announcement returns. There is no noticeable reversal of this effect; after 30 days, abnormal returns are 0.91 percentage points lower. Intangibles talk also (weakly) predicts a decrease in the operating performance measured by a change in return on assets over the next year. Additionally, analysts decrease bidder stock recommendations following takeover announcements rich in intangibles talk. All these findings are robust to controlling for many other variables, such as the general disclosure quality of a company and the extent to which management typically uses intangibles talk on earnings conference calls, and to several other checks.

Why does the market react negatively to intangibles talk? We find no clear evidence that intangibles talk reflects an underlying agency problem between managers and shareholders: For 
example, on the one hand the market responds (insignificantly) less negatively to intangibles talk when the bidder executive team has strong incentives to increase the share price, but it also responds somewhat more negatively when institutional investors own an important stake in the bidder.

By contrast, we find more convincing evidence that intangibles talk is linked to overoptimism. Specifically, first, CEOs and top executives are more likely to purchase stock when they talk more about intangible assets in the takeover announcements. Second, we draw on the insight of Officer et al. (2009) that rational, risk-aware acquirers should be more likely to use stock as the method of payment for hard-to-value targets. The reason is that buying such a company with cash puts all the risk on the bidder: If it turns out to be a bad deal, the bidders suffer, whereas the target shareholders received the cash. Indeed, we confirm that intangiblesheavy targets tend to be bought with stock. However, deals described with lots of intangibles talk are more likely to be cash-paid deals than stock-swap deals. We interpret this as showing that the acquirer manager's overoptimism shows in his choice of language.

Finally, the market response is more pronounced in large deals. In small deals, intangibles talk receives only a weak negative response for private deals, but a strong negative response for public deals. Moreover, the negative response to intangibles talk is mitigated in deals with bidders in industries with high intangible asset intensity. These results indicate that investors worry most about intangibles talk when intangible assets are less likely to play a major role in the acquisition rationale.

Overall, our results suggest that investors should be (and indeed are) careful when assessing an acquirer's proclamations of the intangible assets involved in a transaction. This is less so because of nefarious motives of self-interested managers who use managerial guff to push through value-destroying deals; rather, managers themselves often seem to believe in the value of deals they describe with intangibles talk.

This paper adds to the fast-growing literature that emphasizes the importance of qualitative aspects of corporate communication and media content. In the context of takeovers, existing studies have mostly considered whether textual analysis of media coverage can help predict how likely a deal is to succeed. Liu and McConnell (2013) find that the probability of abandoning a deal after a negative stock price reaction at the announcement is related to 
the level and the tone of media attention to the proposed transaction; Buehlmaier and Zechner (2017) find that media information released on the announcement day contains information not captured by announcement day stock returns; and Ahern and Sosyura (2014) find that bidders manage media coverage during the private negotiation phase in stock acquisitions, generating a short-lived increase in the acquirer's stock price. Very little work is available on merger announcements. Kimbrough and Louis (2011) study merger-related disclosure in conference calls and merger announcements. They show that managers use conference calls to signal information to the market. They do not study intangibles. ${ }^{3}$

The paper also adds to the literature on managerial backgrounds and behavioral biases in the context of takeovers, in particular on the roles of overoptimism and overconfidence. In his seminal work, Roll (1986) offers an explanation of negative takeover announcement returns in the form of managerial overconfidence, the "hubris hypothesis." Malmendier and Tate (2008) find that the probability that a CEO undertakes an acquisition is higher if the CEO is classified as overconfident. Moreover, overconfident CEOs overpay for target companies and undertake value-destroying mergers. Ferris et al. (2013) study international M\&As and find that CEO overconfidence helps to explain the frequencies of acquisitions and the use of cash to finance a merger deal. Custódio and Metzger (2013) show that when the acquirer's CEO has experience in the target industry, the acquirer's abnormal announcement returns are higher. Aktas et al. (2016) study acquirer and target CEO narcissism. We add to this literature by providing further evidence that over-excited CEOs may engage in value-destroying acquisitions, and that this may be revealed in the wording of the announcement.

Our paper is also related to growing research emphasizing the importance of intangible assets in corporate value in general and in corporate takeovers specifically. On the general level, the perception of firm value has evolved over time from a mostly real asset driven to intangible based valuation. This is analyzed in particular in the comprehensive work by Lev (2000), Lev (2005), and Lev (2012). He attributes the rising importance of intangibles to two major factors: the sharp growth in business competition and the commoditization of physical assets. On the more specific level of takeovers and R\%D, Phillips and Zhdanov (2013) show that an active

\footnotetext{
${ }^{3}$ After completing the draft of this paper, we became aware of a study by Filip et al. (2017), who also analyze the description of intangibles in merger press releases, albeit in a much smaller sample. They also find a more likely negative market reaction to disclosures about intangible resources. They do not analyze completion speed, nor do they provide an analysis distinguishing agency and overoptimism explanations.
} 
acquisition market affects firm incentives to innovate and conduct R\&D. Bena and Li (2014) find that patent portfolios and R\&D expenses determine whether a firm will be an acquirer or a target. They conclude that synergies obtained from combining innovation capabilities are important drivers of acquisitions. Chen et al. (2018) show that a firm's propensity to acquire another firm increases after a competitor wins an innovation award. More broadly on the topic of intangibles, Lys and Yehuda (2015) find that private takeover targets have significantly more intangible assets than do public targets. John et al. (2015) and Tate and Yang (2016) study the role of labor mobility in acquisitions, and Ouimet and Zarutskie (2016) use the appearance of references to skilled workers in $10-\mathrm{K}$ statements to show that some firms pursue mergers with an objective of acquiring and retaining the target firm's employees. Li et al. (2018) measure organization capital by capitalized selling, general, and administrative (SG\&A) expenses and show that it predicts superior deal performance. Frésard et al. (2017) show that localized intangibles explain acquisitions of foreign targets. We contribute to this literature by examining bidder communication regarding intangibles in the deal, and the market reaction to such communication.

Finally, this paper adds to the literature that uses textual analysis to provide insight on otherwise difficult to capture issues. For example, some work has established textual measures of financial constraints (Buehlmaier and Whited, 2018; Bodnaruk et al., 2015; Hoberg and Maksimovic, 2015). Others have used 10-Ks to investigate product market competition (Hoberg and Phillips, 2010). Moreover, a vast literature, surveyed in Loughran and McDonald (2016), has considered linguistic tone (which we control for). Our analysis uses textual analysis to provide a new view on intangibles.

The paper proceeds as follows. Section 2 presents our sample selection and data. In particular, it discusses the textual analysis methodology and introduces the intangibles words dictionary. Section 3 studies what explains intangibles talk. Section 4 presents empirical results for how intangibles talk predicts deal completion speed and probability, abnormal returns, and post-merger performance, and an analysis of which factors may contribute to the observed outcomes. It also offers a battery of robustness checks. Section 5 concludes. 


\section{Data}

\subsection{Deals and takeover announcements}

Our data set is composed of corporate takeover deals from 2002 to 2016, collected from SDC and matched to CRSP and COMPUSTAT data. We begin by downloading all announced acquisitions where the bidder is a public company domiciled in the United States, whether the target is a public or private company. ${ }^{4}$ Following Moeller et al. (2004), we collect transactions with at least $\$ 1$ million deal value and $1 \%$ relative size (deal value to bidder market capitalization ratio). We exclude deals that are labeled as recapitalizations, repurchases, self-tenders, or exchange offers, as in Bargeron et al. (2008). We require that the bidder owns at least $80 \%$ of the target after the purchase in case of completed deals, and not more than $15 \%$ before the announcement (Schneider and Spalt, 2017). Following standard practice in the literature, we exclude from the sample bidders that operate in regulated utilities (SIC code 4900-4999) or in the financial industry (SIC code 6000-6999) and bidders with negative book equity. We further require each bidder to match on the CRSP and COMPUSTAT databases. We require that annual financial data for the calculation of the control variables (see below) are available in COMPUSTAT for each bidder, and that the Peters and Taylor (2017) data on intangible capital (see below) are available on WRDS. We extract data for the most recent annual report that is filed not more than a year before the announcement.

The corresponding takeover announcements, filed as $8-\mathrm{K}$ forms, are then downloaded from the EDGAR platform, the Electronic Data Gathering, Analysis, and Retrieval system, which performs automated collection and distribution of data and public filings by companies and others who are required by law to file forms with the SEC. Public companies must file an 8-K form with the SEC within four business days to announce material events that shareholders should know about. Form 8-K is a "current report." It is not filed in the regular time intervals, but is triggered by a significant event like a CEO departure or an M\&A. Only 8-Ks filed no

\footnotetext{
${ }^{4}$ Bidders that are labeled as government, investor, joint venture, mutually owned, subsidiary, private, or have unknown public status are excluded from the sample. The same list of restrictions applies to targets except for private status.
} 
later than 4 business days after the announcement date of the deal are used in the analysis. ${ }^{5}$ Table SA.1 summarizes the sample construction. The final takeover sample consists of 3,036 deals.

Several databases provide additional data needed for testing our hypotheses. Analyst stock buy-sell recommendations are from I/B/E/S (Recommendations - Summary Statistics section). Insider trading data are from Thomson Reuters Insider Filings. Managerial incentives, computed as in Core and Guay (2002) and Coles et al. (2006) are taken from Lalitha Naveen's website. Institutional investor (13F) stock holdings are downloaded from Thomson Reuters. Managerial skill data, as in Demerjian et al. (2012), is drawn from Peter Demerjian's website. ${ }^{6}$ Earnings conference call transcripts are from Thomson Reuters Street Events.

\subsection{Textual analysis of takeover announcements}

\subsubsection{8-K parsing}

We analyze announcements following a common practice in the textual analysis literature, a "bag of words" approach. This approach is based on parsing announcement files into vectors of words and word counts. We exclude footers ${ }^{7}$ as they commonly contain template language that is not useful in measuring text variables of interest. We split words by space and delete all leading and trailing non-alphabetical characters using regular expressions. This procedure automatically removes numbers. Finally, the parsed text is matched to dictionaries to obtain word frequencies.

\footnotetext{
${ }^{5}$ The download and announcement identification procedure is described in Supplementary Appendix Section D.1. EDGAR and SDC do not have a linking identifier. SDC, however, provides 6-digit CUSIPs that can be used to link SDC to CRSP to obtain PERMNOs, which in turn provide a link to COMPUSTAT, which gives us CIK codes. These CIK codes can be used to download 8-K filings that contain announcements from EDGAR. There are 62 deals with a missing CIK in the sample. We find the missing identifiers in EDGAR using the bidder name reported by SDC.

${ }^{6}$ We use the 2016 version of these data to maximize the coverage, but the results also hold with the prior vintage (which covers fewer years and uses a different method).

${ }^{7}$ As a footer starting point we take the forward-looking disclaimer.
} 


\subsubsection{Intangibles talk dictionary}

Our focus is to evaluate the effect of what bidder executives disclose about intangible assets in takeover announcements. We opt for a simple and replicable approach in this analysis, a word counting approach, using a list of relevant words. The extant literature on textual analysis in finance stresses the importance of using word lists that reflect financial jargon. ${ }^{8}$ To our knowledge, there is no such a list for intangibles talk measurement.

To develop our word list, we draw on a number of studies on the role of intangible assets and firm capabilities Hall (1992), Lev (2005) and Lev (2012). These works do not offer well-defined sets of intangibles words, but they are all rich in describing and listing various types of these assets. Hall (1992), for example, lists trade-marks, patents, copyright, registered designs, contracts, trade secrets, reputation, networks, know-how, and culture as general intangible categories. He explains that the analysis of intangible assets should play a major role in the strategic management process and highlights the link between competitive advantage, capability differentials and intangible resources. Lev (2005) lists general categories and points out growing importance of intangibles assets. Lev (2012) emphasizes voluntary disclosure about intangibles to address the shrinking relevance of accounting information.

The list we compile contains 213 words and phrases in total; see Table 1. This list includes the words and phrases that identify or describe intangibles found in one of the abovecited works. Following Loughran and McDonald (2011), we add the plural form of nouns, and the simple past tense, the past participle, gerund and the third person present tense for verbs. ${ }^{9}$ For example, once we include word patent, we add patents, patented and patenting as well. Furthermore, we add words that are either synonyms or have a very similar meaning in the financial jargon as the words from the studies, for instance, we accompany word networks with alliances, relations, relationships and connections.

We did not reverse engineer or "optimize" the word list. Indeed, we will see below that our word list gives plausible results in a cross-industry comparison, but there are also some weaknesses. Future work may profitably adjust the list. We also recognize that more

\footnotetext{
${ }^{8}$ See Loughran and McDonald (2016).

${ }^{9}$ Adverbs and adjectives are not included. However, we find qualitatively similar results even if we include them in the word list.
} 
sophisticated methods, such as machine learning, are likely to do a superior job at capturing intangibles talk.

[Table 1 ABOUT HERE]

Loughran and McDonald (2016) suggest to check word frequency when constructing a dictionary since words tend to follow a power law distribution - a distribution that features a small number of high-frequency words and a large number of low-frequency words. This phenomenon is known as Zipf's law and it raises concerns that certain words can potentially have a large impact on the results. The word frequencies in Figure 1 seem to be intuitive and show no signs of any obvious misclassifications. The 3 most frequent intangibles words (1\% of words from our list), services, solutions, and customers, account for $17 \%$ of the intangibles word count across all acquisition announcements in the sample (21\% when also counting their singular forms). This is significantly smaller than the $44 \%$ that Loughran and McDonald (2016) find for the top $1 \%$ of negative words in the sample of $10-\mathrm{K} / \mathrm{Q}$ filings.

\section{[Figure 1 ABOUT HERE]}

We use the standard approach of proportional weighting, that is word list counts divided by the total number of words in the analyzed text. Accordingly, we define \% Intangibles talk as the number of intangibles words divided by the total number of words in announcement $i$, expressed as a percentage:

$$
\% \text { Intangibles talk } k_{i}=\frac{\text { Intangibles } \text { words }_{i}}{\text { Total } \text { words }_{i}} \cdot 100
$$

\subsubsection{Other textual variables}

We expect announcements to be fairly positive and definitive overall, but there may still be informative variation across announcements. \% Uncertainty and \% Strong modal variables are the percentages of uncertain and strong modal words from the Loughran and McDonald (2016) word list, respectively. We also measure the linguistic tone of the announcement. Although 
Loughran and McDonald (2016) caution against the use of positive words, we are here specifically interested in whether companies may "hype" a transaction by using a high number of positive words, and whether the market sees through such a ploy. Negative words may be interpreted as reflecting a degree of cautiousness. We thus define (net) Negativity of announcement $i$ as:

$$
\text { Negativity }_{i}=\frac{\text { Negative } \text { word }_{i}-\text { Positive }_{\text {word }}}{\text { Negative } \text { words }_{i}+\text { Positive } \text { words }_{i}+1} .
$$

We also control for Text length, the (natural logarithm of the) number of words in the announcement. In the robustness checks, we also use positive and negative frequencies separately, with identical inferences. There, we also use other textual variables, such as average sentence length. Finally, we also use another self-designed word list, a list of "synergy" words (for details see the robustness section).

\subsection{Main deal and firm variables}

Table 2 defines all main variables. Our main dependent variables are an indicator for whether the acquisition was completed; the days to completion; the announcement return and the medium-term return; the change in operating performance of the combined entity one to three years after the transaction; analyst responses; and insider trades. These variables are standard (but we describe them in greater detail below as we go through the analysis).

[Table 2 ABOUT HERE]

Our controls for bidder, target and deal characteristics are also standard. The set of bidder control variables include market-to-book ratio, market capitalization and return on assets (ROA). The main target control variables are its public status, deal relative size, defined as deal size as a fraction of bidder market capitalization, and intangible assets. As deal characteristics we use payment method, tender offer, cross-industry, multiple bidder, cross-border, and friendly deal dummies. Cross-industry deals involve targets with a two-digit SIC code other than that of the bidder. When we analyze deal completion probability, we include two additional dummy variables, indicating the existence of target termination fees and acquirer termination fees. Additionally, we include year and industry fixed effects in all regression 
specifications to control for common time trends and unobservable industry heterogeneity. All continuous control variables (ROA, market-to-book ratio, market capitalization, relative size, deal size, intangible assets and their relative size) are winsorized at the 1st and 99th percentiles.

We will begin the analysis by testing whether bidder management talks more about intangibles when the bidder or the target has more intangible assets. Measuring those assets directly is challenging, and we use three proxies (all of which are only available for public companies). For each of them, we use the ratio of intangible assets to the book value of target total assets (IA/AT), what we refer to as intangible asset intensity. Very similar qualitative inferences hold also when using the log value of intangible assets.

Our primary measure of intangible assets (Intan. assets ${ }_{P T}$ ) is the estimated replacement cost of the target's intangible capital (Peters and Taylor, 2017). These authors recognize that the major part of intangibles arise from expensed activities, for example, a firm's spending to develop knowledge, patents, and software, advertising to build brand capital or employee training to build human capital. They, therefore, define intangible assets as the sum of the firm's externally purchased and internally created intangible capital. Externally purchased intangible capital is measured as the book value of intangible assets. Internally created intangible capital is computed as the sum of the replacement cost of the firm's knowledge capital, which is the portion of intangible capital that comes from research and development (R\&D), and the replacement cost of the firm's organization capital, the portion of intangible capital that comes from selling, general, and administrative (SG\&A) expenses. ${ }^{10}$ The Peters and Taylor (2017) measure is available in WRDS.

Second, another widely used measure is the book value of intangible assets (Intan. assets $_{b v}$ ), which is available in COMPUSTAT. The book value of intangible assets does not fully reflect their real size as accounting systems generally do not keep track of internally generated intangible assets. ${ }^{11}$ Third, we compute target intangible assets as deal size minus tangible assets, which in turn are calculated as total assets minus the book value of intangible assets. The constructed variable (Intan. assets $_{a c q}$ ) essentially quantifies the bidder's estimate of

\footnotetext{
${ }^{10}$ This latter part of the Peters and Taylor (2017) of intangible capital is similar to the Li et al. (2018) measure of organizational capital, which they compute by cumulating the deflated value of SG\&A expenses.

${ }^{11}$ Under U.S. GAAP, ASC 350-20-25-3 states, "Costs of internally developing, maintaining, or restoring intangible assets (including goodwill) that are not specifically identifiable, that have indeterminate lives, or that are inherent in a continuing business and related to an entity as a whole, shall be recognized as an expense when incurred." - https ://www . fasb.org/resources/ccurl/731/820/fas142.pdf
} 
the target intangible assets in the context of the specific deal. This measure has the advantage that it uses current information and captures internally generated intangibles, but it has the disadvantage that, apart from target intangible assets, it also captures synergies and possible over- or underpayment. By construction, this measure is not available for bidders.

\subsection{Summary statistics}

Table 3 presents summary statistics. On average, $2.38 \%$ of takeover announcements' words come from the intangibles words list, with substantial variation across announcements. Interestingly, the distribution is not heavily skewed, as also seen in the median value of $2.30 \%$. (We study industry variation, time trends, and other determinants of intangibles talk below.)

As would be expected in the description of a major corporate investment, the announcements are dominated by positive words $(1.41 \%)$ relative to negative words $(0.34 \%)$, resulting in average negativity of -0.55 . Words that might carry a negative message, such as strong modal and uncertainty words, are also not so frequent, namely $0.19 \%$ and $0.43 \%$ respectively. $^{12}$

\section{[Table 3 ABOUT HERE]}

The sample has a positive event period bidder cumulative abnormal return (CAR) of $0.39 \%$ on average $(0.22 \%$ median CAR). As is usual, in public deals, bidders reap significantly negative returns on average $(-1.28 \%)$, in contrast to what happens in private deals $(1.27 \%){ }^{13}$ The target CAR, by contrast, is significantly positive, with a mean (median) value of $24.6 \%$ $(20.7 \%) .{ }^{14}$ In our sample, $93 \%$ of deals are completed, which is somewhat more than is typi-

\footnotetext{
${ }^{12}$ These numbers can be compared to average negativity (as defined here), strong modal word usage, and uncertainty of $-0.38,0.63 \%$, and $0.84 \%$, respectively, on earnings conference calls (Druz et al., 2018).

${ }^{13}$ Moeller et al. (2004) report average bidder CARs of $1.496 \%$ for private deals and $-1.022 \%$ for public deals. In a more recent study, Schneider and Spalt (2017) compute bidder CARs of $1.44 \%$ for non-public and $-1.39 \%$ for private deals, respectively.

${ }^{14}$ Similarly, Bargeron et al. (2008) find that shareholders of firms acquired by public firms gain $29.5 \%$ on average over the 3 days around the announcement of the acquisition.
} 
cally the case. ${ }^{15}$ The average (median) time from the announcement to the deal completion is about 55 (34) days. The average abnormal increase in operating performance ( $\triangle \mathrm{ROA}$ ) following the acquisition is $0.86 \%$ over one year and $0.58 \%$ over three years.

The size of intangible assets varies substantially depending on the measure we use. The book value is the smallest, followed by the Peters and Taylor (2017) measure, and, where available, the measure that proxies for the size of acquired intangibles using actual deal size. ${ }^{16}$

\section{Which announcements feature intangibles talk?}

We begin our analysis by analyzing intangibles talk over time, across industries, and across deals. Figure 2 plots the time series of intangibles talk in the full sample and for private and public target deal announcements separately. There is little discernible variation in intangibles talk over time, though there does appear to exist a modest downward trend over time, particularly among public deals (which exhibit significantly less intangibles talk, as detailed further below).

Next, Figure 3 shows, as expected, that the magnitude of bidder management talk about intangibles depends on the industry sector of the target. ${ }^{17}$ For example, the highest intangibles talk industries among the Fama-French 48 industries, Business services, Computers, and Electrical equipment are nearly three times richer in intangibles talk than are the lowest three, Precious metals, Restaurants, hotels, motels, and Petroleum and natural gas. The later three indeed heavily rely on tangible assets in contrast to the ones at the top of the intangibles talk list which, as one would expect, are technology intensive industries. As such, our classification

\footnotetext{
${ }^{15}$ For the 1979-2003 period, Officer (2007) reports that 95\% of 2,829 offers in SDC for unlisted stand-alone targets for are successful versus $77 \%$ of 4,559 offers for publicly traded targets. This combines to an $84 \%$ overall completion rate. In our sample, $96 \%$ of 1,736 offers for private targets and $88 \%$ of 740 offers for publicly traded targets are completed. The difference between the full sample statistics can, therefore, be attributed to the relatively higher proportion of private targets and the higher completion rate of public target deals in our sample. The latter is likely due to relatively smaller number of hostile deals in our sample, which were more common during the "corporate raiders" era in the 1980s.

${ }^{16}$ Table SA. 2 reports the correlation between the measures of target intangible assets. The correlation coefficients for the measures of absolute intangible asset size (Panel A) are all positive and significant. The smallest coefficient (59.4\%) is the one between the book value and the estimate of acquired intangibles, and the largest one is between the book value and the PT measures (83.3\%). However, the relative measures (Panel B) are not significantly correlated, with the exception of the correlation between the ratios using the estimate of acquired intangibles and the PT measures, which is statistically different from zero, but still small in magnitude (10.0\%).

${ }^{17} \mathrm{~A}$ quite similar picture arises when using bidder industries.
} 
captures plausible variation. We acknowledge that the classification is not perfect. For example, acquisition announcements in the Pharma industry use relatively few of our intangibles words, even though one might expect these deals to involve a high percentage of intangibles. More sophisticated and perhaps industry-specific classification methods could yield further insights here, but would raise concerns about data mining.

\section{[Figure 2 ABOUT HERE]}

\section{[Figure 3 ABOUT HERE]}

Columns (1) and (2) in Panel A of Table 4 show that bidder intangible assets (whether measured by the Peters and Taylor (2017) method or by book value) are significantly positively related with intangibles talk. However, once we control for industry fixed effects in columns (3) and (4), firm-specific intangible assets do not offer further explanatory power. Industry and year fixed effects alone explain $21 \%$ of the variation in intangibles talk. Columns (5) and (6) reveal that deal size and the target public status dummy explain an additional $10 \%$ of the variation (31\% in total). Both variables enter negatively and significantly. This is consistent with the intuition that private and small firms, such as start-ups, rely more heavily on intangible assets, for example innovation potential. ${ }^{18}$ Conversely, these regressions suggest that when an announcement of an acquisition of a public target uses a high frequency of intangibles words, this is unusual.

In additional checks below, we also examine the role of general disclosure quality, typical talk on earnings conference calls, and managerial skill. The robustness section shows that these do not strongly correlate with intangibles talk. Because adding either of these controls reduces the sample size, we do not include them in the main regressions, but repeat all analysis with them in the robustness analysis in Section 4.4, with unchanged inferences.

In additional, untabulated analysis, we also investigate whether deal characteristics correlate with intangibles talk. We do not find much significant variation (except that intangibles talk is more prevalent when the payment mode is cash, a theme we pick up further below).

\footnotetext{
${ }^{18}$ Indeed, Lys and Yehuda (2015) find that private takeover targets have significantly more intangible assets than do public targets. Moreover, Phillips and Zhdanov (2013) present evidence of a negative relation between firm size and the innovation process.
} 
In any case, we control for a range of deal variables in the further analysis. We also find that takeover announcements with more intangibles talk use more positive and fewer negative words, as well as more strong modal words. We control for these additional linguistic features in what follows.

\section{[Table 4 ABOUT HERE]}

In Panel B, we focus on public targets, which offer accounting information not available for private firms. Specifically, we consider three measures of target intangible assets: the estimated replacement cost of target's intangibles (Peters and Taylor, 2017), the book value, and the estimate of the acquired intangibles. ${ }^{19}$ Strikingly, none of specifications yields significant coefficients.

Overall, these results suggest that while intangibles talk predictably varies with industry characteristics, the relative importance of target intangible assets in the target's total assets does not explain the use of intangibles talk, and neither do the bidder's intangible assets (beyond their correlation with industry). These results beg several questions: Is intangibles talk just managerial guff? If so, are investors fooled? Or do these results mean that there is new and valuable information in the announcements? That is, do managers perhaps reveal insights into the value of a deal that would not be seen in observables? Do investors respond to it? Does the phrasing of announcements reveal something about management's eagerness to conclude the deal? We turn to these questions next.

\section{What does intangibles talk reveal?}

\subsection{Deal completion and intangibles talk}

We begin our analysis of the predictive power of intangibles talk in takeover announcements by examining whether it reveals something about the decisiveness with which management pursues the transaction. We hypothesize that, holding the nature of the deal constant, a bidder management team that (correctly or incorrectly) sees intangible value in the deal, will seek to

\footnotetext{
${ }^{19}$ We do not have these data for international targets.
} 
complete the deal more quickly. One possible motivation for this is that the manager of the acquirer might think that his shareholders may worry that the deal will not go through. In such a situation, he will try to quickly convey certainty to all parties involved by completing the deal. It is also possible that a manager who feels that he has better prospects to complete the deal may feel that he has some latitude to use intangibles talk.

To test this idea, we look at variation in the amount of time from the announcement till the completion date, given that the bidder acquires the target, and the deal completion probability. (Time to completion is a useful complement to the completion probability because, after all, most deals do get completed.)

\section{[Figure 4 ABOUT HERE]}

Figure 4 presents graphical evidence that intangibles talk strongly predicts deal completion speed and probability. The top panel shows that the completion rate shows a strong, positive relation with the proportion of intangibles words: In the lowest quintile of intangibles talk, less than $86 \%$ of deals are completed, whereas in the highest quintile, more $96 \%$ are completed. The completion rate increases monotonically over the five quintiles. Strikingly, the completion time measured in days exhibits almost a linearly decreasing trend across intangibles talk quintiles: In the lowest quintile of intangibles talk, deals take around 100 days to complete. By contrast, when an announcement is in the highest quintile of intangibles talk, managers seem to be in a hurry: after less than 50 days, the average deal is completed. Overall, these patterns provide suggestive evidence that the managerial desire to quickly acquire the target is indeed reflected in the frequency of intangibles words.

Other factors may play a role as well. For example, acquisitions of private targets involve more intangibles talk, but these acquisitions are expected to close substantially faster (given their smaller complexity on average). Also, there might be differences across industries and over time. Before turning to regressions with a large set of controls, the bottom panel of Figure 4 repeats the graphical analysis, but adjusts all variables for industry, year, and public target status. A very similar picture emerges.

Formally, to explore whether the observed patterns are driven by bidder, target, or deal 
characteristics, we estimate the following probit regression:

$$
\operatorname{Pr}\left(C_{i}=1\right) \propto \exp \left(\alpha+\beta_{1} I T_{i}+\sum_{n} \beta_{n} T V_{i, n}+\sum_{m} \beta_{m} C V_{i, m}+I n d+Y r\right)
$$

where $C$ is a dummy equal to 1 for deals that are completed, $I T$ is intangibles talk, $T V$ are other textual variables, and $C V$ are deal, bidder and target control variables for deal $i$.

The second test involves an OLS regression that estimates DTC, the number of days between the announcement and completion date for deal $i$. This analysis, obviously, examines only completed deals:

$$
D T C_{i}\left(C_{i}=1\right)=\alpha+\beta_{1} I T_{i}+\sum_{n} \beta_{n} T V_{i, n}+\sum_{m} \beta_{m} C V_{i, m}+I n d+Y r
$$

The other variables remain as in the previous model.

In both models, we include 2-digit SIC bidder industry (Ind) and year ( $Y r$ ) fixed effects. We cluster standard errors by the announcement year to capture the correlation between observations over time. ${ }^{20}$

\section{[Table 5 ABOUT HERE]}

Table 5 reports the regression results for the two models. They provide further evidence for the hypothesis suggested by Figure 4 above: Specifically, regressions (1) and (2) imply that, even controlling for a rich set of bidder, target, and deal characteristics, there is a statistically and economically significant association between the extent of intangibles talk and the completion rate of deals. A one percentage point difference in intangibles talk implies a 1.6 to 2.3 percentage point greater completion probability. Similarly, specifications (3) and (4) show that the bidders who talk more about intangible assets in their announcements conclude a deal in a significantly shorter time period, given that the target is acquired. One percentage point more in intangibles talk shortens the deal completion period by 3.2 to 4.1 days.

Other textual features of the announcement are also revealing: When announcements,

\footnotetext{
${ }^{20}$ Alternatively, we cluster standard errors by 2-digit SIC industry. The results remain similar throughout the entire analysis. Yet alternatively, we use Fama-French 48 industries, with identical inferences. Finally, our results also remain robust when using industry-year fixed effects (which accounts for the possibility of industry-specific merger waves, for example).
} 
which tend to be positive, are somewhat less positive, the completion probability is lower and completed deals take longer. Uncertain words portend a somewhat lower completion rate. The other control variables largely have signs in line with the existing literature.

Overall, the evidence strongly indicates that intangibles talk predicts faster and more likely deal completion.

\title{
4.2 Does intangibles talk describe better deals?
}

We have found that there is positive and significant relation between intangibles talk in the takeover announcements and the observed speed and likelihood of completion of the deal. We consider three potential explanations for this relation: (1) advantageous private information, (2) agency problems, and (3) bidder overoptimism. The explanations are not mutually exclusive ex ante. To distinguish between explanation (1) and the other two, we exploit the market reaction to the takeover announcement and the actual ex-post performance of bidders. To distinguish between (2) and (3), we draw on cross-sectional variation in the market reactions as well as on choices of payment modes and insider trading choices.

\subsubsection{Does intangibles talk convey advantageous information?}

We investigate abnormal returns (around the announcement and in the medium run), operating performance, and analyst responses after takeover announcements.

\begin{abstract}
Abnormal returns
Bidders emphasizing intangibles in takeover announcements may possess private beneficial information about the target firm potential. As such, their eagerness to acquire the target would be well-motivated, and they would be simply referring more frequently to intangible aspects as they try to communicate this information and their excitement to the shareholders. Thus, this Advantageous Information Hypothesis predicts more positive bidder announcement returns after more pronounced intangibles talk. By contrast, both the Agency Hypothesis and the Overoptimism Hypotheses predict a negative relation. Under the former, managers are exploiting their
\end{abstract}


power to engage in deals that are good for them but bad for their shareholders; under the letter, managerial hubris leads executives to embark on deals that are poor for all.

We measure bidder announcement returns as $\operatorname{CAR}(-1,1)$, the 3-day cumulative abnormal returns for the bidder firm using the Carhart four-factor model, around the announcement. Model parameters are estimated over days $(-280,-31){ }^{21}$

\section{[Figure 5 ABOUT HERE]}

Strikingly, Figure 5 shows a clear, negative relation between bidder abnormal returns and the frequency of intangibles words. Recall that on average announcement returns are $0.48 \%$. In the top quintile of intangibles talk, announcement returns are roughly $0 \%$, whereas in the lowest quintile, they are about $1 \%$, a sizable spread around the average returns. The lower panel of Figure 5 adjusts for industry, year, and public target status. The picture remains virtually unchanged, though the spread between announcement returns in the high and low intangibles talk quintiles now becomes bigger.

To formally investigate the relation between bidder returns and intangibles talk, we estimate the following regression:

$$
C A R_{i}(-1,1)=\alpha+\beta_{1} I T_{i}+\sum_{n} \beta_{n} T V_{i, n}+\sum_{m} \beta_{m} C V_{i, m}+I n d+Y r
$$

where $C A R(-1,1)$ is the bidder announcement CAR, IT is intangibles talk, $T V$ are other textual variables, and $C V$ are deal, bidder and target control variables for deal $i$. Again, we also include industry (Ind) and year ( $Y r$ ) fixed effects, and we cluster standard errors by the announcement year. As before, the results are robust to the use of industry-year fixed effects and industry-year clustering.

\section{[Table 6 ABOUT HERE]}

Table 6 shows that intangibles talk enters negatively and significantly in both specifications. Because the standard deviation of intangibles talk is (very close to) one, regressions

\footnotetext{
${ }^{21}$ We use the same interval to estimate the benchmark returns as Schneider and Spalt (2017). They use the market model instead of the Carhart four-factor model.
} 
(1) and (2) imply that a one standard deviation higher intangibles talk results in 0.37 to 0.45 percentage points lower abnormal returns, a sizable effect.

These effects do not revert. Of course, it gets harder to significantly explain returns over longer time horizons due to the increased noise. However, as column (3) shows, after 30 days, high-intangibles talks firms still experience a discount in abnormal returns of $-0.85 \%$ on average. The point estimate is similar, though a bit bigger at $-0.91 \%$, when including other textual variables in column (4).

The control variables have the usual signs. In addition, regression (2) shows that the market responds (weakly) to the linguistic tone initially, but later reverts. Uncertainty and the extent of modal word usage in the takeover announcement do not explain announcement returns. In the full regressions shown, intangible assets of the bidder are not significantly associated with the market reaction in our sample. ${ }^{22}$

Overall, these results show that investors respond more negatively to acquisition announcements with more intangibles talk.

\section{Post-acquisition performance}

To assess further whether intangibles talk is related to actual deal quality, we look at the postacquisition combined entity performance. We consider Return on Assets (ROA), defined as EBITDA over assets. We allow for performance to accrue over time as it may take time to generate value from intangible assets. Therefore, we examine ROA changes from year 0 to year 1 , and from year 0 to year 3 , where year 0 is defined as the year of acquisition. We follow Frésard et al. (2017) and address underlying industry trends by contrasting an acquirer's performance to that of its industry peers. For each acquirer, we construct a portfolio of peers that do not differ more than $50 \%$ in size from the acquirer, operate in the same 2-digit SIC industry, and are not involved in any acquisition during a six-year period surrounding the transaction.

\footnotetext{
${ }^{22} \mathrm{Li}$ et al. (2018) show that bidders with higher organizational capital secure higher announcement returns. We also find a positive, albeit insignificant association of intangible assets when not controlling for the announcementlevel text variables and some other controls. While the Li et al. (2018) measure of organizational capital is based on a similar logic as the Peters and Taylor (2017) measure of intangible capital that we use, there are important differences. For example, Peters and Taylor (2017) add the internally generated intangible capital to prior acquired intangible capital, and they use different depreciation rates for R\&D expenses in different industries. In a sample of non-high-tech firms, where the latter difference is likely to play a smaller role, we also find a positive association of intangible asset intensity on announcement returns.
} 
The benchmark is calculated as a mean performance of each portfolio, which is then subtracted from that of the acquirers.

\section{[Table 7 ABOUT HERE]}

Table 7 reports the results of cross-sectional regressions for the post-acquisition change in performance. The regression coefficients of intangibles talk prove consistently negative for both 1-year and 3-year period. However, statistical significance obtains only for the 1-year window. Overall, the evidence is broadly consistent with the findings from the CAR analysis, that is, acquiring firms do not refer to intangibles to communicate advantageous private information about the target.

\section{Analyst stock recommendations}

Do financial analysts respond to the information in takeover announcements? To answer, we compute the change in the median analyst recommendation and regress it on intangibles talk. The change is defined as a difference between the earliest available median recommendation that is calculated within the 7-60 days period after the takeover announcement and the most recent median recommendation calculated within the 7-60 days period before the takeover announcement. Thomson Reuters calculates median recommendations by assigning to each contributing analyst's recommendation an integer based on the standardized Thomson Reuters recommendation scale and calculating a real number median. The (inversed) scale is as follows: 5. Strong Buy, 4. Buy, 3. Hold, 2. Underperform, 1. Sell.

Column 3 of Table 7 reports the results of the test. We find that the intangibles talk coefficients in all specifications are negative and significant, meaning that takeover announcements rich in intangibles talk are related to the magnitude of stock recommendation downgrade. Finding even a small effect in such an analysis is impressive, given that on average analysts are known to be reluctant to downgrade their recommendations (Conrad et al., 2006; Michaely and Womack, 1999).

\section{Summary}


Overall, the evidence from each of these dependent variables - stock returns (both immediate and medium-term), operational performance changes, and analyst recommendation changes suggests that when the bidder management team refers to intangible assets, it is not conveying advantageous private information to the investors. Higher levels of intangibles talk in the takeover announcements are rather an indicator of poor managerial decisions leading to the acquisition.

\subsubsection{Agency or overoptimism?}

The negative market response to the takeover announcements with relatively high level of intangibles talk suggest that the bidder managers are either conflicted and are pursuing their own objectives, or that they are overoptimistic about the deal.

\section{Testing for agency problems}

The Agency Hypothesis posits that managers who expect to privately benefit (e.g., through an empire-building motive) from a takeover, even one that destroys value, will refer to intangible aspects in an attempt to justify a deal and bolster their private returns. The hypothesis predicts that the effect of intangibles talk on deal completion and announcement abnormal returns is stronger for bidders that have a more pronounced agency problem. To proxy for the extent of the agency problem we use variables that measure the quality of corporate governance at a firm.

We present results for two measures. ${ }^{23}$ Our first governance measure is institutional stock ownership. The likelihood that managers will announce a low quality takeover decreases with institutional stock ownership as these investors' incentives to monitor the managers increase with the stake. Our second measure is executive incentives. Intuitively, executives whose wealth depends more on the share price are better aligned with shareholder welfare, which should lead them to seek out value-increasing takeovers and avoid value-destroying deals. A standard measure of executives incentives is "equity delta," the dollar change in executive wealth from stock and stock options per percent change of the share price. Lalitha Naveen provides data of these incentives on her website, computed following Core and Guay (2002)

\footnotetext{
${ }^{23}$ In unreported tests, we use a third measure, the entrenchment index (E-index) of Bebchuk et al. (2008), which we download from their website. The sample is reduced as their index stops before the end of the sample period. The inferences from this analysis are the same as those reported in this section.
} 
and Coles et al. (2006). We sum delta of all disclosed executives to get a measure of the total management team's incentives. The data cover firms in ExecuComp, which cuts our sample approximately in half. We define a dummy equal to one for firms with below industry-median executive delta, and a dummy equal to one for firms with below median institutional ownership. Then, we interact these dummies with intangibles talk.

\section{[Table 8 ABOUT HERE]}

The regression results are in Table 8. Panel A presents results for bidder CAR regressions, and Panel B reports regressions for completion speed. The results are mixed. For example, even deals announced with lots of intangibles talk do not get executed faster when institutional investors own an important stake in the bidder. This could point to an agency story. However, the market responds responds somewhat more negatively when institutional investors own an important stake in the bidder, which is arguably contrary to the agency hypothesis but in line with a story under which bad deals are priced more efficiently in such firms. At the same time, a less negative market response to intangibles talk when the bidder executive team has strong incentives to increase the share price would be in line with the agency hypothesis. But the corresponding interaction coefficient is insignificant, and so is the interaction between executive incentives and intangibles talk in the completion speed regressions.

Overall, we find no strong evidence in favor of the Agency Hypothesis.

\section{Testing for overoptimism}

Next, we analyze the Overoptimism Hypothesis. This hypothesis states that intangibles talk in the takeover announcements is due to managerial overoptimism about the value of the deal. Both a higher likelihood of deal completion and the negative market reaction are consistent with this hypothesis. In order to test whether what managers disclose about intangibles reflects their own views and, therefore, their optimism about the takeover, we conduct two tests: First, the payment mode can be revealing. Second, we examine whether managers put their own money where their mouth is.

As concerns the payment mode, we draw on the insights of Officer et al. (2009). They show that acquirer returns are significantly higher in stock-swap acquisitions of difficult-to- 
value targets (as measured, in their case, by $R \& D$ intensity and idiosyncratic return volatility). Following their logic, rational, risk-aware acquirers should be more likely to use stock as the method of payment for intangibles-heavy targets. The reason is that buying such a company with stock is a smart move from a risk-management perspective. If it turns out to be a bad deal, then the target shareholders will also suffer. By contrast, buying a hard-to-value company with cash puts all the risk on the bidder. If it turns out to be a bad deal, the bidder shareholders suffer, whereas the target shareholders received the cash. Extending this logic, if intangibles talk indicates overoptimism, we would expect that deals described with lots of intangibles talk are more likely to be cash-paid deals than stock-swap deals. Table 9 shows that this is exactly what we find. (The table also confirms that bidders are less likely to use cash when they themselves are intangibles rich or when the target has high intangibles intensity.)

Overall, we interpret these results as showing that the acquirer manager's overoptimism shows in his choice of language.

\section{[Table 9 ABOUT HERE]}

For our second test, we examine insider trading by CEOs and other top executives. ${ }^{24}$ Under the Overoptimism Hypothesis, we expect to observe bidder executives to increase their stock holdings after the deal announcement. ${ }^{25}$ We also analyze trading behavior of board members who do not hold an executive position. We expect CEOs and other executives to display more optimism in their actions than other board members, since in most cases it is the executives who initiate the takeover.

Following Chung et al. (2018), we construct a trading window for each announcement that begins 2 days after the announcement and ends 60 days after the announcement or the effective day if it comes first. We assign a positive sign to buy and negative to sell transactions, and then compute the total number of shares traded for each group. A group is labeled as a net buyer if the total number of shares traded over the analyzed window is positive, i.e., if the number of shares purchased exceeds the number of shares sold.

\section{[Table 10 ABOUT HERE]}

\footnotetext{
${ }^{24}$ The top executives group include following roles: CFO (Chief Financial Officer), COO (Chief Operating Officer), CIO (Chief Investment Officer) and CTO (Chief Technology Officer).

${ }^{25}$ It would be illegal to trade before announcing the deal.
} 
Panel A of Table 10 reports the results of probit regressions that measure the propensity for the bidder CEO to purchase the stock. Panel B does the same for CEO or other Executives. Panel C looks at non-executive directors.

In sum, consistent with the hypothesis we find that bidder CEOs and other top executives are more likely to purchase stock when they talk more about intangible aspects in the takeover announcements. Column (1) shows baseline regressions. The average marginal effect on the probability of CEOs to buy stock associated with a one percentage point difference in intangibles talk is $1.9 \%$. We also find a strongly significant effect for the aggregate group of top executives. The relation is positive, but not significant for board members. Column (2) recognizes that a possible explanation for why CEOs and top executives buy shares after a takeover announcement with considerable intangibles talk is that they just respond to the stock price decrease. This story predicts a significant negative relation between the bidder CAR and propensity to buy for each individual group, and this is what we find. The intangibles talk coefficients are practically not affected by bidder abnormal returns when compared to the results from the first specification. Finally, column (3) includes other deal characteristics and control variables. The effects are reduced in size, but the probability that in aggregate the group of top executives buy shares still increases by $1.7 \%$ with a one percentage point increase in intangibles talk, a sizable effect relative to the unconditional probability of $14 \%$.

\section{Summary}

Overall, this evidence of post-announcement stock purchases by executives suggests that intangibles talk is indeed related to managerial overoptimism about the deal quality. By contrast, there is no strong evidence in favor of the agency-based explanation.

\subsection{Deal characteristics}

As a final piece of evidence linking intangibles talk and the value of a deal, we consider several aspects of cross-sectional heterogeneity.

[Table 11 ABOUT HERE] 
First, we consider the public-private dimension, an important theme in the M\&A literature. To do so, we interact intangibles talk with the public target dummy. Table 11 shows the results. Column (1) of Panel A shows that the interaction coefficient in the bidder CAR regression is negative and sizable, but not statistically significant. However, columns (2) and (3) highlight an interesting and intuitive dependency on deal size. Specifically, in large deals (size above the median), intangibles talk is substantially more significantly relevant than in the full sample: the main effect implies that a one percentage point higher intangibles talk results in 0.86 percentage points lower abnormal returns. In this size bracket, intangibles talk receives a similar response in public and private deals, as seen from the completely insignificant interaction term. By contrast, column (3) shows that in small deals, intangibles talk receives only a weak negative response for private deals, but a strong negative response for public deals. This may be because the market pays more attention for these deals, or is more easily able to assess whether intangibles talk actually indicates value of the acquisition.

A separate analysis, in Supplementary Appendix Table SA.3, splits the sample and considers public deals separately. Consistent with the interaction analysis, we find a large and significantly negative effect of intangibles talk on announcement returns among public deals. That analysis also provides an opportunity to analyze target and combined returns. We find that intangibles talk is positively, but insignificantly associated with target abnormal returns. The net effect in the form of combined returns is still negative.

Finally, we examine whether intangibles talk is more negatively related to CAR when the bidder uses intangibles talk in situations where talk about intangibles is atypical. Column (4) shows that the negative market response to intangibles talk is not a high-tech industry phenomenon. ${ }^{26}$ By contrast, column (5) of Table 11 does show that when bidder management refers frequently to intangibles when its industry is characterized by low intangible asset intensity, shareholders on average are not fond of such deals.

\subsection{Robustness}

Table 12 and Table 13 present all main regressions with various robustness checks.

\footnotetext{
${ }^{26}$ As in Baginski et al. (2004), we identify companies in high-tech industries as those whose primary industry is: drugs (SIC codes 2833-2836), research and development services (8731-8734), programming (7371-7379), computers (3570-3577), or electronics (3600-3674).
} 
First, we control for disclosure quality. Chen et al. (2015) show that the extent of detail with which a firm presents its financial results, the disaggregation quality $(D Q)$ of financial statements, can serve as a measure of disclosure quality that is available for a large sample of firms. $D Q$ and intangibles talk are positively correlated, so potentially this could explain our findings. However, Panel A of Table 12 shows that it is intangibles talk that remains significant in all our main regressions even after controlling for disclosure quality differences.

Second, anecdotal evidence suggests that firms often talk about "synergies" in the context of acquisitions. This is a conceptually different topic than intangibles; after all, synergies through combining entities can also be obtained for tangible assets and activities through cost savings, for example. As such, "synergies talk" may deserve a separate inquiry. We have constructed, again drawing on keywords appearing in the business literature, a preliminary word list aiming to capture such talk. ${ }^{27}$ Intangibles talk and synergies talk are positively, but not very highly correlated (0.19). Panel B of Table 12 shows that while managerial talk about synergies does appear to predict higher likelihood of completing the deal and an increase in profitability, it is not a significant determinant of the other dependent variables. Intangibles talk remains significant throughout even controlling for synergies talk.

Third, we check whether it is the takeover-announcement-specific intangibles talk that is reflected in stock price reactions and the other dependent variables. To conduct this exercise, we measure intangibles talk by managers of each company in earnings conference calls. ${ }^{28}$ That is, we use our word list to compute the frequency of intangibles talk in each conference call in the sample period. We then take an average, by firm, thus computing the typical "intangibles talk style" of a company. To avoid reducing the sample sizes further, for firms for which we cannot find matching conference call transcripts we replace intangibles talk in conference calls with the industry average and include a dummy variable equal to 1 (and 0 elsewhere) to absorb the effect of this adjustment in our empirical specifications. Panel $\mathrm{C}$ of Table 12 shows that the results for intangibles talk in merger announcements remain unchanged. The market generally responds negatively to merger announcements of firms who usually use a lot of intangibles talk

\footnotetext{
${ }^{27}$ The list comprises the following words: alliance, collaborate, collaborated, collaborates, collaborating, collaboration, combination, combine, combined, combined effort, combines, combining, complement, complementary, complemented, complementing, complements, cooperate, cooperated, cooperates, cooperating, cooperation, fit, fits, fitted, fitting, joint, joint effort, match, matched, matches, matching, synergies, synergy, team effort, team work, together, working together.

${ }^{28}$ We use the presentation and answers portions of the call to pick up the typical managerial communication style.
} 
(as seen in the negative and significant coefficient of intangibles talk in conference calls), but the communication in the merger announcement is considered separately by market participants. This is for good reason, as this communication predicts completion speed and insider trading.

Fourth, it is conceivable that intangibles talk relates to the competence of managers, or to their backgrounds. Demerjian et al. (2012) estimate managerial ability using data envelopment analysis: Firms that are more efficient in generating revenues than one would expect based on their characteristics are posited to be run by more competent managers. A merit of this method is that can be applied to a wide range of firms. We use their percentile rank measure (from 0 to 1 , by industry and year), though the results also hold with the cardinal score. Untabulated results show that managerial ability is unrelated to intangibles talk. Panel A of Table 13 shows that although the sample size is reduced, controlling for managerial ability does not change our results regarding the role of intangibles talk in explaining stock price reactions, payment method, and insider trading. ${ }^{29}$ In untabulated results, we find (using data ranging until 2007 provided by Custódio et al. (2013)) that general ability, having an MBA, or having an Ivy league degree also do not correlate with intangibles talk. However, the number of observations drops to around 500 in this analysis.

Fifth, controlling for industry-year fixed effects, while demanding in this setting given the relatively limited sample size, does not substantially change the results, as seen in Panel B of Table 13. Only the effect of intangibles talk on operating performance becomes insignificant. Finally, Panel C confirms that the results are not driven by very large or very small deals (that is, deals in the $1^{\text {st }}$ and $99^{\text {th }}$ percentiles of deal size).

The results are also robust if we control for positive and negative word frequencies separately. We have also experimented with controlling for other textual aspects of the takeover announcement. For example, we have controlled for its (textual) complexity by computing the average of words per sentence. ${ }^{30}$ The results remain robust controlling for this measure of complexity.

\footnotetext{
${ }^{29}$ It is somewhat surprising that in our sample managerial ability is unrelated to announcement returns.

${ }^{30}$ To parse for sentences, we follow Loughran and McDonald (2014) and first remove abbreviations and numbers, and then assume that the remaining periods are sentence terminations.
} 


\section{Conclusion}

Intangible assets represent an important component of firm value. Indeed, their importance seems to be growing. For example, Lev (2012) documents a secular decline of the ability of accounting data to explain share price differences across companies. It is, therefore, of interest to know how managers communicate about intangibles. This paper presents the first study quantifying intangibles talk, defined as the frequency of words associated with intangible assets, in financial text. We construct a novel word list of intangible-related words to capture what a financial release about a merger says about this hard-to-value asset class. Intangibles are conceptually particularly important in the context of mergers and acquisitions. Therefore, we apply the list to corporate takeover announcements in the U.S. from 2002 to 2016. The analysis reveals considerable variation in the use of intangibles talk in the announcements. The amount that managers talk about intangible aspects significantly varies across industries and depends on some deal and target characteristics. Notably, however, at least in public deals, the intangible assets of the target explain little of the usage of intangible words in the takeover announcements.

Intangibles talk is not just inconsequential managerial guff. It is positively related to the deal completion speed and probability - but negatively related to announcement returns. The strong negative market reaction to intangibles talk suggests that managers do not use intangibles words to disclose advantageous private information about the target. The agency explanation of the relation between intangibles talk and negative announcement returns receives no strong support in data. An analysis of payment mode choices and of insider trades reveals, by contrast, evidence of managerial overoptimism about deals they describe with intangibles talk. We speculate that this overoptimism partly arises because the importance of intangibles is a relatively new phenomenon. As such, business school teachings and prior managerial experience are not (yet) sufficiently helpful in assessing and communicating about deals along this dimension. Overall, these results suggest that it can pay off for investors to carefully study the phraseology of takeover announcements. 


\section{References}

Ahern, Kenneth R, and Denis Sosyura, 2014, Who writes the news? Corporate press releases during merger negotiations, The Journal of Finance 69, 241-291.

Aktas, Nihat, Eric De Bodt, Helen Bollaert, and Richard Roll, 2016, CEO narcissism and the takeover process: From private initiation to deal completion, Journal of Financial and Quantitative Analysis 51, 113-137.

Baginski, Stephen P, John M Hassell, and Michael D Kimbrough, 2004, Why do managers explain their earnings forecasts?, Journal of Accounting Research 42, 1-29.

Bargeron, Leonce L, Frederik P Schlingemann, René M Stulz, and Chad J Zutter, 2008, Why do private acquirers pay so little compared to public acquirers?, Journal of Financial Economics 89, 375-390.

Bebchuk, Lucian, Alma Cohen, and Allen Ferrell, 2008, What matters in corporate governance?, The Review of Financial Studies 22, 783-827.

Bena, Jan, and Kai Li, 2014, Corporate innovations and mergers and acquisitions, The Journal of Finance 69, 1923-1960.

Betton, Sandra, B Espen Eckbo, and Karin S Thorburn, 2008, Corporate takeovers, in B Espen Eckbo, ed., Handbook of Corporate Finance: Empirical Corporate Finance, chapter 15, 291-430 (Elsevier/North-Holland).

Bodnaruk, Andriy, Tim Loughran, and Bill McDonald, 2015, Using 10-K text to gauge financial constraints, Journal of Financial and Quantitative Analysis 50, 623-646.

Buehlmaier, Matthias M, and Toni M Whited, 2018, Are financial constraints priced? Evidence from textual analysis, Review of Financial Studies 31, 2693-2728.

Buehlmaier, Matthias M, and Josef Zechner, 2017, Financial media, price discovery, and merger arbitrage, Working paper .

Chen, I-Ju, Po-Hsuan Hsu, Micah S. Officer, and Yanzhi Wang, 2018, The Oscar goes to...: Peer pressure, innovation competition, and takeovers, Working paper .

Chen, Shuping, Bin Miao, and Terry Shevlin, 2015, A new measure of disclosure quality: The level of disaggregation of accounting data in annual reports, Journal of Accounting Research $53,1017-1054$.

Chung, Kiseo, Clifton T Green, and Breno Schmidt, 2018, CEO home bias and corporate acquisitions, Working paper .

Coles, John, Naveen Daniel, and Lalitha Naveen, 2006, Managerial incentives and risk-taking, Journal of Financial Economics 79, 431-468.

Conrad, Jennifer, Bradford Cornell, Wayne R Landsman, and Brian R Rountree, 2006, How do analyst recommendations respond to major news?, Journal of Financial and Quantitative Analysis 41, 25-49. 
Core, John E., and Wayne R. Guay, 2002, Estimating the value of employee stock option portfolios and their sensitivities to price and volatility, Journal of Accounting Research 40, 613629.

Custódio, Cláudia, Miguel Ferreira, and Pedro Matos, 2013, Generalists versus specialists: Lifetime work experience and CEO pay, Journal of Financial Economics 108, 471-492.

Custódio, Cláudia, and Daniel Metzger, 2013, How do CEOs matter? The effect of industry expertise on acquisition returns, The Review of Financial Studies 26, 2008-2047.

Demerjian, Peter, Baruch Lev, and Sarah McVay, 2012, Quantifying managerial ability: A new measure and validity tests, Management Science 58, 1229-1248.

Druz, Marina, Ivan Petzev, Alexander F Wagner, and Richard J Zeckhauser, 2018, When managers change their tone, analysts and investors change their tune, Working paper .

Ferris, Stephen P, Narayanan Jayaraman, and Sanjiv Sabherwal, 2013, CEO overconfidence and international merger and acquisition activity, Journal of Financial and Quantitative Analysis 48, 137-164.

Filip, Andrei, Gerald J. Lobo, Luc Paugam, and Hervé Stolowy, 2017, Disclosures about intangible resources in m\&a press releases and quality of the deal, Working paper .

Frésard, Laurent, Ulrich Hege, and Gordon Phillips, 2017, Extending industry specialization through cross-border acquisitions, The Review of Financial Studies 30, 1539-1582.

Grinstein, Yaniv, and Paul Hribar, 2004, CEO compensation and incentives: Evidence from m\&a bonuses, Journal of Financial Economics 73, 119-143.

Hall, Richard, 1992, The strategic analysis of intangible resources, Strategic Management Journal 13, 135-144.

Hoberg, Gerard, and Vojislav Maksimovic, 2015, Redefining financial constraints: A text-based analysis, Review of Financial Studies 28, 1312-1352.

Hoberg, Gerard, and Gordon Phillips, 2010, Product market synergies and competition in mergers and acquisitions: A text-based analysis, Review of Financial Studies 23, 3773-3811.

Jensen, Michael C, 1986, Agency costs of free cash flow, corporate finance, and takeovers, The American Economic Review 76, 323-329.

Jensen, Michael C, and William H Meckling, 1976, Theory of the firm: Managerial behavior, agency costs and ownership structure, Journal of Financial Economics 3, 305-360.

John, Kose, Anzhela Knyazeva, and Diana Knyazeva, 2015, Employee rights and acquisitions, Journal of Financial Economics 118, 49-69.

Kimbrough, Michael D, and Henock Louis, 2011, Voluntary disclosure to influence investor reactions to merger announcements: An examination of conference calls, The Accounting Review 86, 637-667.

Lev, Baruch, 2000, Intangibles: Management, measurement, and reporting (Brookings Institution Press). 
Lev, Baruch, 2005, Intangible assets: Concepts and measurements, in Kimberly KempfLeonard, ed., Encyclopedia of social measurement, volume 2, 299-305 (Elsevier New York, NY).

Lev, Baruch, 2012, Winning investors over: Surprising truths about honesty, earnings guidance, and other ways to boost your stock price, chapter 7, 145-172 (Harvard Business Press).

Li, Kai, Buhui Qiu, and Rui Shen, 2018, Organization capital and mergers and acquisitions, Journal of Financial and Quantitative Analysis 53, 1871-1909.

Liu, Baixiao, and John J McConnell, 2013, The role of the media in corporate governance: Do the media influence managers' capital allocation decisions?, Journal of Financial Economics $110,1-17$.

Loughran, Tim, and Bill McDonald, 2011, When is a liability not a liability? Textual analysis, dictionaries, and 10-Ks, The Journal of Finance 66, 35-65.

Loughran, Tim, and Bill McDonald, 2014, Measuring readability in financial disclosures, The Journal of Finance 69, 1643-1671.

Loughran, Tim, and Bill McDonald, 2016, Textual analysis in accounting and finance: A survey, Journal of Accounting Research 54, 1187-1230.

Lys, Thomas Z, and Nir Yehuda, 2015, Do acquisitions of private targets create higher value? The role of intangible assets acquired, Working paper .

Malmendier, Ulrike, and Geoffrey Tate, 2008, Who makes acquisitions? ceo overconfidence and the market's reaction, Journal of Financial Economics 89, 20-43.

Michaely, Roni, and Kent L Womack, 1999, Conflict of interest and the credibility of underwriter analyst recommendations, The Review of Financial Studies 12, 653-686.

Moeller, Sara B, Frederik P Schlingemann, and René M Stulz, 2004, Firm size and the gains from acquisitions, Journal of Financial Economics 73, 201-228.

Moeller, Sara B, Frederik P Schlingemann, and René M Stulz, 2007, How do diversity of opinion and information asymmetry affect acquirer returns?, Review of Financial Studies 20, 2047-2078.

Morck, Randall, Andrei Shleifer, and Robert W Vishny, 1990, Do managerial objectives drive bad acquisitions?, The Journal of Finance 45, 31-48.

Officer, Micah S, 2007, The price of corporate liquidity: Acquisition discounts for unlisted targets, Journal of Financial Economics 83, 571-598.

Officer, Micah S, Annette B Poulsen, and Mike Stegemoller, 2009, Target-firm information asymmetry and acquirer returns, Review of Finance 13, 467-493.

Ouimet, Paige, and Rebecca Zarutskie, 2016, Acquiring labor, Working paper .

Peters, Ryan H, and Lucian A Taylor, 2017, Intangible capital and the investment-q relation, Journal of Financial Economics 123, 251-272. 
Phillips, Gordon M, and Alexei Zhdanov, 2013, R\&D and the incentives from merger and acquisition activity, Review of Financial Studies 26, 34-78.

Roll, Richard, 1986, The hubris hypothesis of corporate takeovers, Journal of Business 59, 197-216.

Savor, Pavel G, and Qi Lu, 2009, Do stock mergers create value for acquirers?, The Journal of Finance 64, 1061-1097.

Schneider, Christoph, and Oliver G Spalt, 2017, Why does size matter so much for bidder announcement returns?, Working paper .

Tate, Geoffrey A, and Liu Yang, 2016, The human factor in acquisitions: Cross-industry labor mobility and corporate diversification, Working paper . 


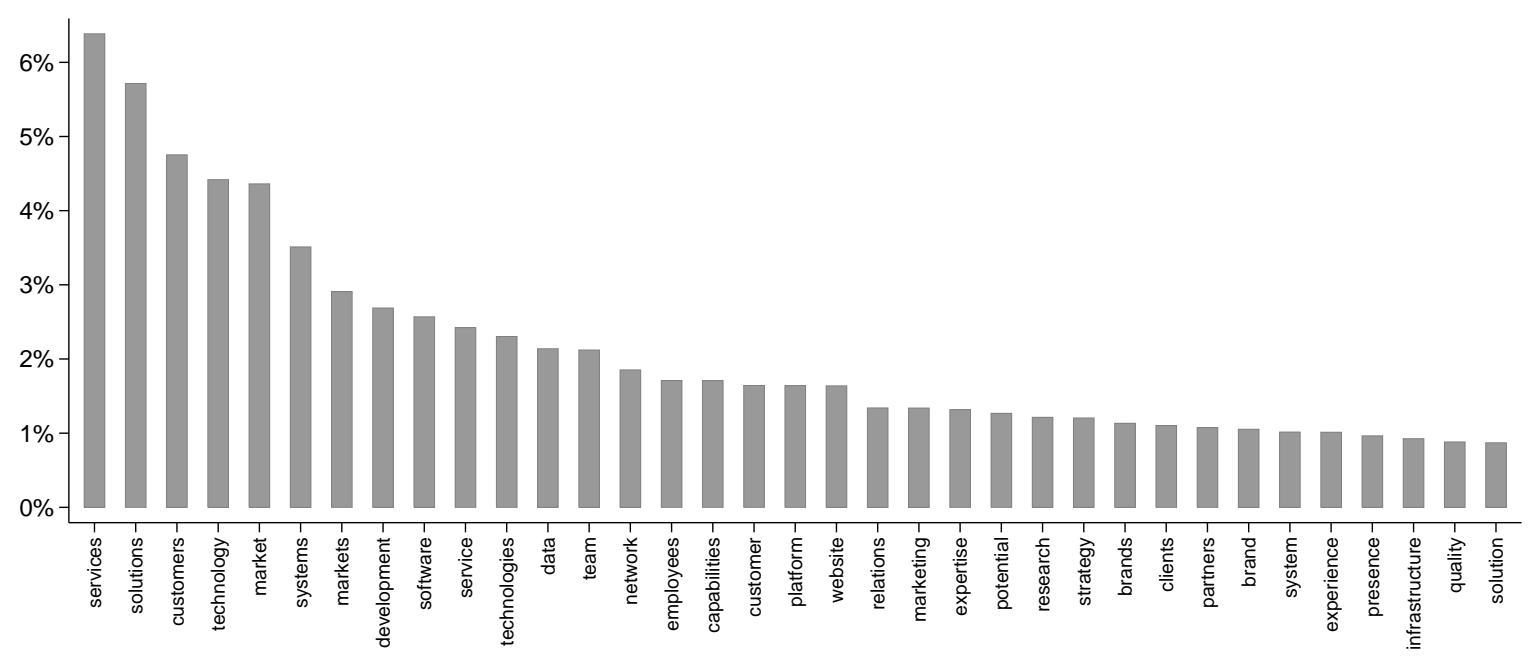

\section{Figure 1: The most frequent intangibles words in takeover announcements}

The figure presents the frequency of 35 most common intangibles words in takeover announcements. It is calculated as a ratio of each word count to the total count of all intangibles words (see 1) occurring in the announcements. The sample consists of 3036 takeover deals announced between January 2002 and December 2016 with a bidder that is a publicly traded company domiciled in the United States. 


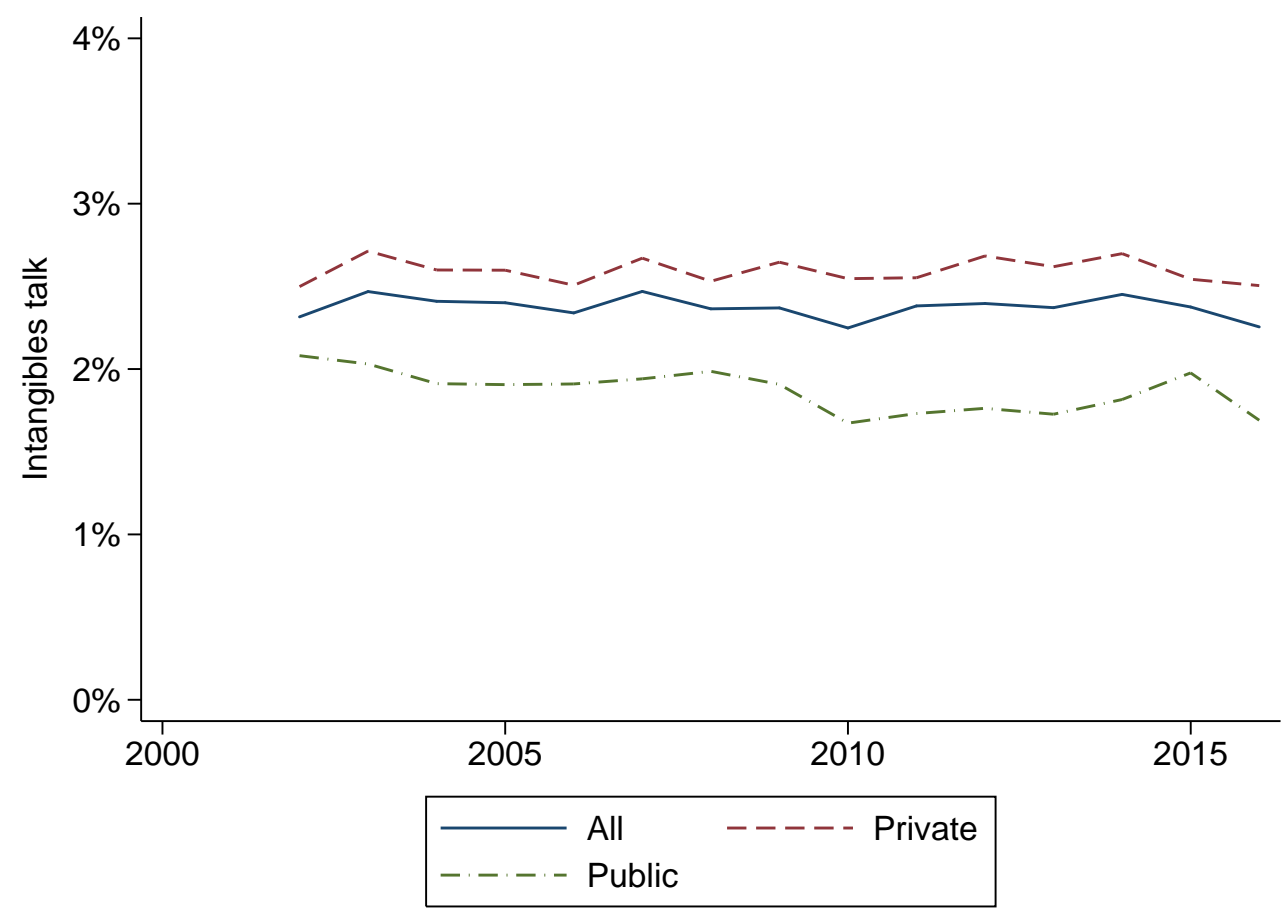

\section{Figure 2: Intangibles talk over time}

This figure plots the average frequency of intangibles words relative to the total word count in takeover announcements over time. The frequency is calculated for the whole sample (solid line) and separately for deals with private and public targets. The sample consists of 3036 takeover deals announced between January 2002 and December 2016 with a bidder that is a publicly traded company domiciled in the United States. 


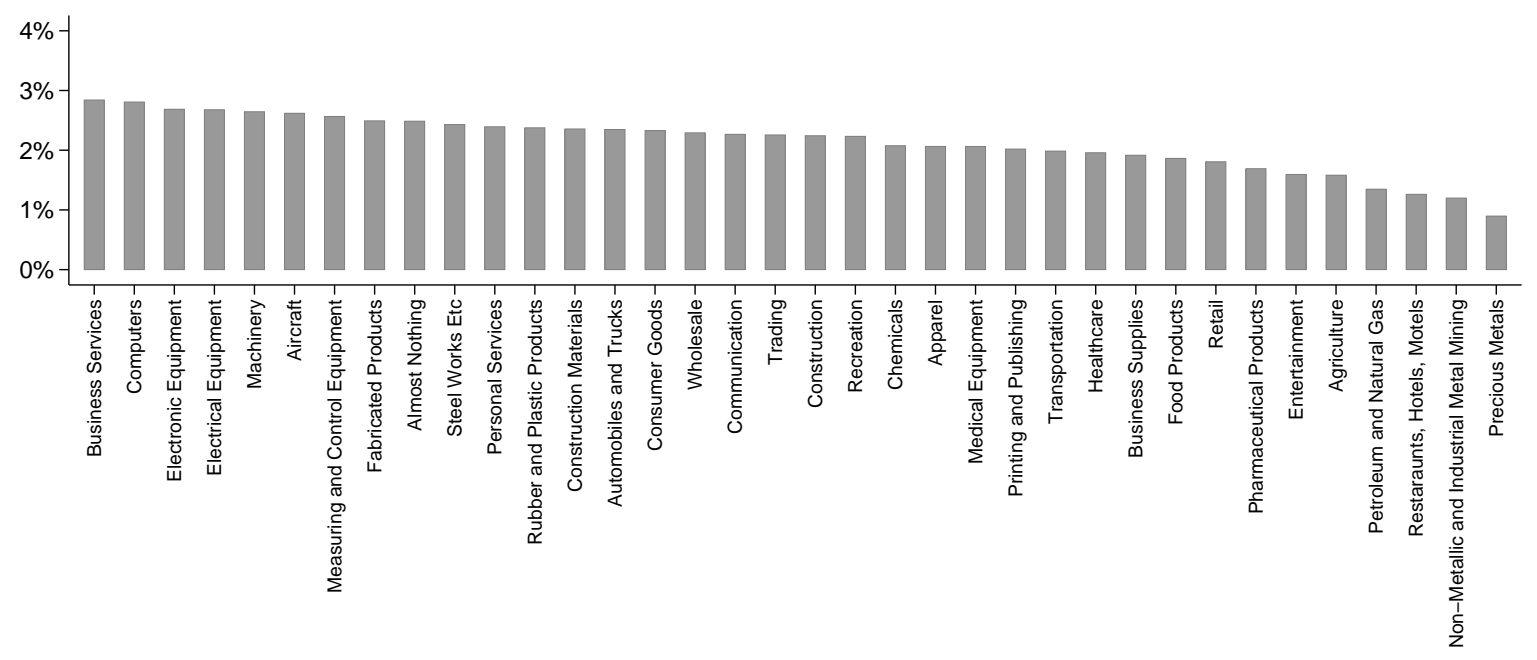

\section{Figure 3: Intangibles words by target industry}

This figure plots the average frequency of intangibles words relative to the total word count in takeover announcements by target Fama-French 48 industries. Industries that have fewer than ten deals are not shown. The sample consists of 3036 takeover deals announced between January 2002 and December 2016 with a bidder that is a publicly traded company domiciled in the United States. 

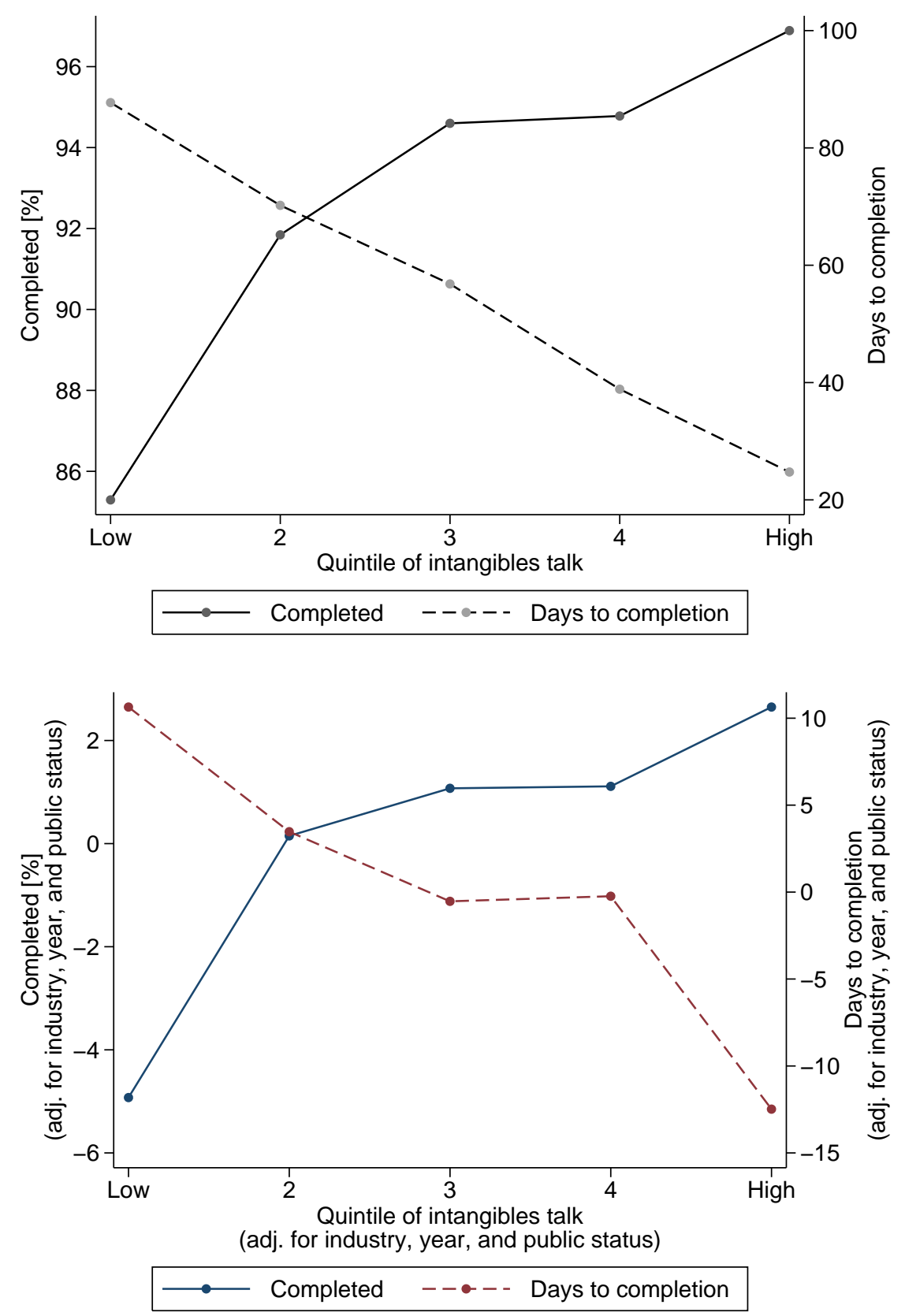

\section{Figure 4: Completion speed and intangibles talk}

The relation between the completion rate and the frequency of intangibles words in the announcement text is shown on the left y-axis. The relation between time to completion and the frequency of intangibles words in the announcement text is shown on the right y-axis. Time to completion is measured by the number of days it takes to complete the deal following the announcement given that the bidder acquires the target. The sample is divided into quintiles of intangibles talk. The top figure summarizes unadjusted data, the bottom figure shows residuals of regressions of each variable on industry and year fixed effects and a dummy indicating whether the target is a public company. Thus, the figure shows actual completion (100\% or $0 \%)$ minus predicted completion probability from a Probit regression in case of the completion rate; actual days to completion minus predicted days to completion from a OLS regression for time to completion; actual intangibles talk minus predicted intangibles talk from a OLS regression. The sample consists of 3036 takeover deals announced between January 2002 and December 2016 with a bidder that is a publicly traded company domiciled in the United States where the control variables discussed in the text are available. 

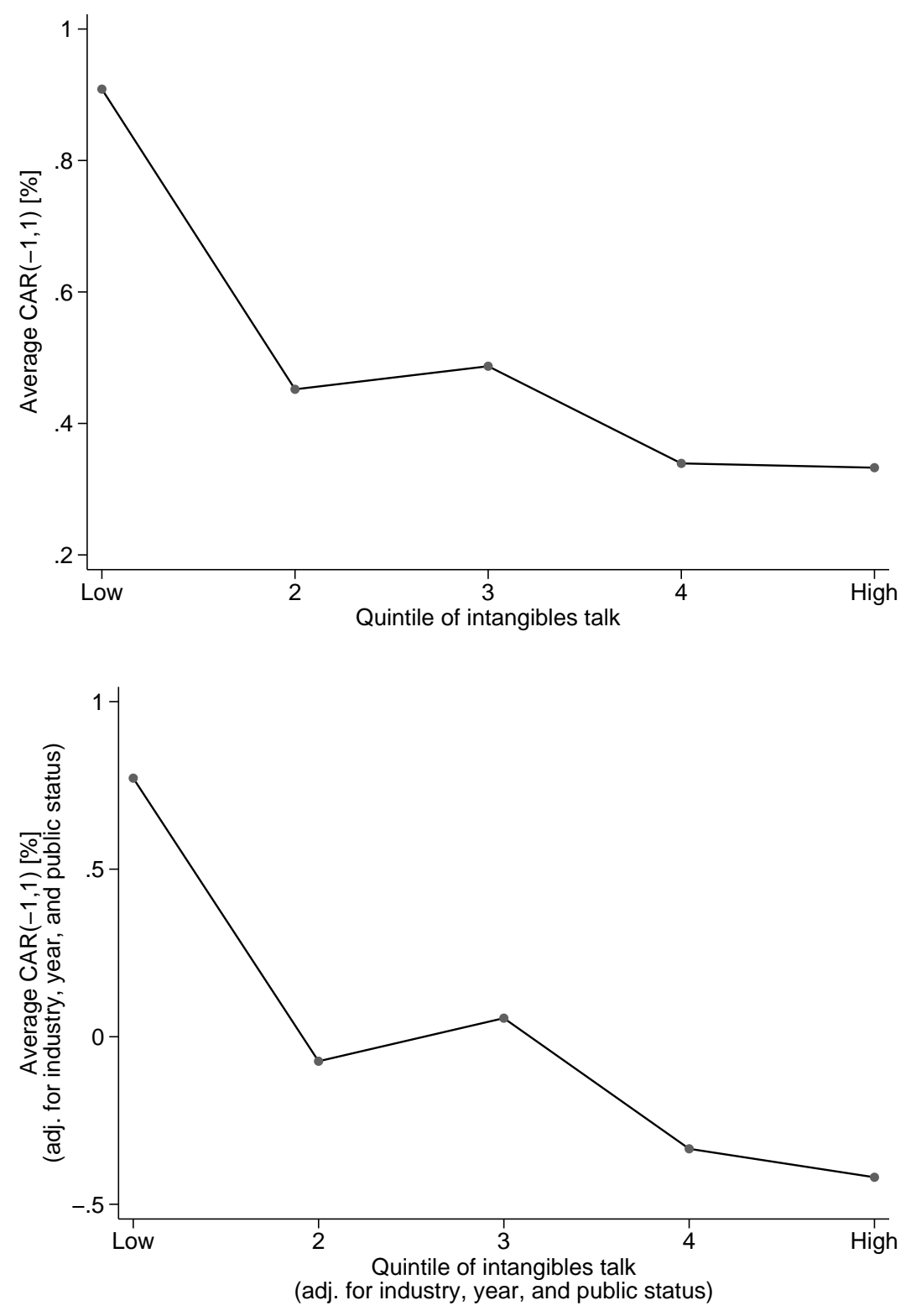

\section{Figure 5: Bidder returns and intangibles talk}

The figure shows the relation between the bidder announcement cumulative abnormal return (CAR) and the frequency of intangibles words in the announcement text. The announcement abnormal return is the cumulative 3-day event period return minus the associated Carhart four-factor model return. Cumulative daily abnormal returns are winsorized at the $1^{\text {st }}$ and $99^{\text {th }}$ percentiles. The figure shows means of this variable in the five quintiles of intangibles talk. The top figure summarizes unadjusted data, the bottom figure shows residuals of OLS regressions of announcement returns and intangibles talk on industry and year fixed effects and a dummy indicating whether the target is a public company. The sample consists of 3036 takeover deals announced between January 2002 and December 2016 with a bidder that is a publicly traded company domiciled in the United States where the control variables discussed in the text are available. 


\section{Table 1: Intangibles word list}

This table shows our intangibles word list. The list includes words and phrases that identify intangibles based on Hall (1992), Lev (2005) and Lev (2012). Following Loughran and McDonald (2011), we add the plural form of nouns, the simple past tense, the past participle, gerund and the third person present tense for verbs. Additionally, we include appropriate synonyms and words with similar meaning.

\begin{tabular}{|c|c|c|c|c|}
\hline & & Intangibles words & & \\
\hline Abilities & Customer relations & Invented & Program & Trade names \\
\hline Ability & Customers & Inventing & Programs & Trade secret \\
\hline Advertising & Data & Invention & Project & Trade secrets \\
\hline Algorithm & Database & Inventions & Projects & Trademark \\
\hline Algortihms & Databases & Invents & Protected design & Trademarks \\
\hline Alliance & Design & Invest & Protected designs & Trade-secret \\
\hline Alliances & Designs & Invested & Qualities & Trade-secrets \\
\hline Authorship & Developed & Investing & Quality & Training \\
\hline Authorships & Development & Investment & $\mathrm{R} \& \mathrm{D}$ & User \\
\hline Brand & Developments & Investments & Registered design & Users \\
\hline Branding & Discoveries & Invests & Registered designs & Website \\
\hline Brands & Discovery & Joint venture & Relation & Websites \\
\hline Business model & Efficiencies & Joint ventures & Relations & Workforce \\
\hline Business models & Efficiency & Knowhow & Relationship & \\
\hline Business process & Employee & Know-how & Relationships & \\
\hline Business processes & Employees & Knowledge & Reputation & \\
\hline Capabilities & Employee-training & Label & Research & \\
\hline Capability & Experience & Labels & Researches & \\
\hline Capacities & Expert & Licence & Rights & \\
\hline Capacity & Expertise & Licences & Risk management & \\
\hline Client & Experts & Logo & Service & \\
\hline Client relations & Footprint & Loyalty & Service mark & \\
\hline Clients & Footprints & Market & Service marks & \\
\hline Collaborate & Formula & Market share & Services & \\
\hline Collaborated & Formulae & Marketing & Site visits & \\
\hline Collaborates & Franchise & Markets & Skill & \\
\hline Collaborating & Franchises & Model & Skills & \\
\hline Collaboration & Goodwill & Models & Software & \\
\hline Competence & HR & Network & Solution & \\
\hline Competences & Human capital & Networks & Solutions & \\
\hline Competencies & Human resources & Order backlog & Strategies & \\
\hline Competency & Incentive & Organization capital & Strategy & \\
\hline Connections & Incentives & Organizational design & Structure & \\
\hline Connectivity & Infrastructure & Organizational designs & Structures & \\
\hline Consumer & Infrastructures & Partner & Supply chain & \\
\hline Consumers & Innovate & Partners & Supply chains & \\
\hline Contract & Innovated & Patent & System & \\
\hline Contracts & Innovates & Patented & Systems & \\
\hline Copyright & Innovating & Patents & Talent & \\
\hline Copyrights & Innovation & Platform & Talents & \\
\hline Cost savings & Innovations & Platforms & Team & \\
\hline Coverage & Innovator & Potential & Teams & \\
\hline Coverages & Innovators & Potentials & Teamwork & \\
\hline Culture & Intangible assets & Presence & Technologies & \\
\hline Customer & Intangibles & Private-label & Technology & \\
\hline Customer base & Intellectual capital & Private-labels & Tool & \\
\hline Customer bases & Intellectual property & Process & Tools & \\
\hline Customer list & Internet activities & Processes & Trade mark & \\
\hline Customer lists & Internet activity & Product pipeline & Trade marks & \\
\hline Customer relation & Invent & Productivity & Trade name & \\
\hline
\end{tabular}




\section{Table 2: Variable definitions and sources}

This table defines the main variables used in the analysis. They are obtained directly from or constructed using Compustat, CRSP, EDGAR, ExecuComp, I/B/E/S (Recommendations - Summary Statistics section), SDC, Thomson Reuters institutional (13F) stock holdings and Thomson Reuters Insider Filings (IF) databases.

\begin{tabular}{|c|c|c|}
\hline Variable & Definition & Source \\
\hline \multicolumn{3}{|l|}{ Textual variables } \\
\hline$\%$ Intangibles talk & $\begin{array}{l}\text { Ratio of the number of intangibles words to the total number of words in the takeover } \\
\text { announcement, expressed in } \% \text {. }\end{array}$ & EDGAR \\
\hline$\%$ Negative & $\begin{array}{l}\text { Ratio of the number of negative words to the total number of words in the takeover } \\
\text { announcement, expressed in } \% \text {. }\end{array}$ & EDGAR \\
\hline$\%$ Positive & $\begin{array}{l}\text { Ratio of the number of positive words to the total number of words in the takeover } \\
\text { announcement, expressed in } \% \text {. }\end{array}$ & EDGAR \\
\hline$\%$ Strong modal & $\begin{array}{l}\text { Ratio of the number of strong modal words to the total number of words in the } \\
\text { takeover announcement, expressed in } \% \text {. }\end{array}$ & EDGAR \\
\hline$\%$ Uncertainty & $\begin{array}{l}\text { Ratio of the number of uncertainty words to the total number of words in the takeover } \\
\text { announcement, expressed in } \% \text {. }\end{array}$ & EDGAR \\
\hline $\ln ($ Text length) & Natural logarithm of the number of words in the takeover announcement. & EDGAR \\
\hline Negativity & $\begin{array}{l}\text { Ratio of the difference between the number of negative and positive words in the } \\
\text { takeover announcement to their sum. }\end{array}$ & EDGAR \\
\hline \multicolumn{3}{|l|}{ Dependent variables } \\
\hline $\operatorname{CAR}(-1,1)$ & $\begin{array}{l}\text { Cumulative abnormal returns (in } \% \text { ) for the bidder firm from day }-1 \text { to day } 1 \text { calcu- } \\
\text { lated using the Carhart four-factor model. Model parameters are estimated over days } \\
(-280,-31) \text {. }\end{array}$ & CRSP \\
\hline CAR(-1,30) & $\begin{array}{l}\text { Cumulative abnormal returns (in } \% \text { ) for the bidder firm from day }-1 \text { to day } 30 \text { calcu- } \\
\text { lated using the Carhart four-factor model. Model parameters are estimated over days } \\
(-280,-31) \text {. }\end{array}$ & CRSP \\
\hline $\mathrm{CAR}_{\mathrm{t}}(-1,1)$ & $\begin{array}{l}\text { 3-day cumulative abnormal returns (in } \% \text { ) for the target firm calculated using the } \\
\text { Carhart four-factor model. Model parameters are estimated over days }(-280,-31) \text {. }\end{array}$ & CRSP \\
\hline V.w. comb. CAR(-1,1) & $\begin{array}{l}\text { Value-weighted average of the bidder and target CAR(-1,1) where weights are cal- } \\
\text { culated as day } 0 \text { market value of equity. The variable is expressed in } \% \text {. }\end{array}$ & CRSP \\
\hline Completed & 1 for completed acquisitions. & SDC \\
\hline Days to completion & Number of days between the effective and announcement dates. & SDC \\
\hline$\Delta \mathrm{ROA}(0, \mathrm{~T})$ & $\begin{array}{l}\text { Acquiring firm T-year post acquisition increase in return on assets benchmarked to } \\
\text { the mean performance of a portfolio of } 2 \text {-digit SIC industry peers that do not differ } \\
\text { more than } 50 \% \text { in size from the acquirer, and are not involved in any acquisition } \\
\text { during a six-year period surrounding the transaction. The variable is expressed in } \\
\text { percentage points. }\end{array}$ & Compustat \\
\hline$\Delta$ Analyst recom. & $\begin{array}{l}\text { Change in the analyst recommendation calculated as a difference between the earli- } \\
\text { est available median recommendation that is calculated within the } 7-60 \text { days period } \\
\text { after the takeover announcement and the most recent median recommendation cal- } \\
\text { culated within the } 7-60 \text { days period before the takeover announcement. Thomson } \\
\text { Reuters calculates median recommendations by assigning to each contributing ana- } \\
\text { lyst's recommendation an integer based on the standardized Thomson Reuters rec- } \\
\text { ommendation scale and calculating a real number median. We construct and use the } \\
\text { inversed scale as follows: } 5 \text {. Strong Buy, } 4 \text {. Buy, 3. Hold, } 2 \text {. Underperform, } 1 \text {. Sell. }\end{array}$ & $\mathrm{I} / \mathrm{B} / \mathrm{E} / \mathrm{S}$ \\
\hline CEO buys & $\begin{array}{l}1 \text { if the number of shares a CEO purchases exceeds the number of shares he sells } \\
\text { over a trading window that begins } 2 \text { days after the announcement and ends } 60 \text { days } \\
\text { after the announcement or the effective day if it comes first. }\end{array}$ & TR IF \\
\hline
\end{tabular}


Table 2 - continued from previous page

\begin{tabular}{|c|c|}
\hline Variable & Definition \\
\hline CEO or Execs buy & 1 if either CEO buys or Top Execs buy or both variables are 1 . \\
\hline Directors buy & $\begin{array}{l}1 \text { if the aggregate number of shares board members purchase exceeds the aggre- } \\
\text { gate number of shares they sell over a trading window that begins } 2 \text { days after the } \\
\text { announcement and ends } 60 \text { days after the announcement or the effective day if it } \\
\text { comes first. Board members who hold an executive role (CEO, CFO, COO, CIO or } \\
\text { CTO) are excluded. }\end{array}$ \\
\hline Top Execs buy & $\begin{array}{l}1 \text { if the aggregate number of shares top executives (CFO, COO, CIO and CTO), } \\
\text { aside from the CEO, purchase exceeds the aggregate number of shares they sell over } \\
\text { a trading window that begins } 2 \text { days after the announcement and ends } 60 \text { days after } \\
\text { the announcement or the effective day if it comes first. }\end{array}$ \\
\hline
\end{tabular}

\section{Measures of intangible assets}

Intan. assets acqt

Intan. assets ${ }_{b v j}$

Intan. assetsPT $j$

$\left(\mathrm{IA}_{\mathrm{acq}} / \mathrm{AT}\right)_{\mathrm{t}}$

$\left(\mathrm{IA}_{\mathrm{bv}} / \mathrm{AT}\right)_{\mathrm{j}}$

$\left(\mathrm{IAPT}_{\mathrm{PT}} / \mathrm{AT}\right)_{\mathrm{j}}$

\section{Control variables}

Acquirer term. fee

Cash

Cross-country

Cross-industry

Deal size

Friendly

High-tech

Low executive incentives
Dollar value of target intangible assets (in millions of US \$) measured as deal size minus the book value of tangible assets of the target [Tangible assets $=$ Total assets (AT) - Intangible assets (INTAN)].

Dollar value of the book value of $j=[\mathrm{b}$ (idder), $\mathrm{t}$ (arget) $]$ intangible assets (in millions of US \$).

Dollar value of $j=[\mathrm{b}($ idder $), \mathrm{t}($ arget) $]$ intangible assets (in millions of US \$) measured as in Peters and Taylor (2017). The measure, labeled as $K_{-i n t}$ and defined as the estimated replacement cost of the firm's intangible capital, is available thorough WRDS.

Ratio of target intangible assets to the book value of target total assets. Intangible assets are measured as deal size minus the book value of tangible assets [Tangible assets $=$ Total assets (AT) - Intangible assets (INTAN)] .

Ratio of the book value of $j=[\mathrm{b}$ (idder), $\mathrm{t}$ (arget) $]$ intangible assets to the book value of target total assets.

Ratio of $j=[\mathrm{b}$ (idder), $\mathrm{t}($ arget $)]$ intangible assets to the book value of target total assets. Intangible assets are measured as in Peters and Taylor (2017). The measure, labeled as $K_{\text {_int }}$ and defined as the estimated replacement cost of the firm's intangible capital, is available thorough WRDS.

TR IF

Compustat, SDC

Compustat

WRDS

Compustat, SDC

Compustat

Compustat, WRDS

SDC

SDC

SDC

SDC

SDC

SDC

SDC

1 when the target belong to the following industries: drugs (SIC codes 2833-2836), research and development services (8731-8734), programming (7371-7379), computers (3570-3577), and electronics (3600-3674), as in Baginski et al. (2004).

Lalitha Naveen price (equity delta, as in Core and Guay (2002) and Coles et al. (2006)).

TR 13F 
Table 2 - continued from previous page

\begin{tabular}{|c|c|c|}
\hline Variable & Definition & Source \\
\hline Market cap & $\begin{array}{l}\text { Bidder market capitalization }[=\text { Share price }(\mathrm{PRCC} \text { _F }) \times \text { Number of shares outstand- } \\
\text { ing }(\mathrm{CSHO})(\text { millions of US } \$)] \text { at the last fiscal year end before the takeover an- } \\
\text { nouncement. }\end{array}$ & Compustat \\
\hline Market-to-book & $\begin{array}{l}\text { Ratio of the bidder market capitalization to its book value of equity [=Total share- } \\
\text { holders' equity (SEQ) + Deferred taxes and investment tax credits (TXDITC) - Pre- } \\
\text { ferred stock liquidating value (PSTKL)] at the last fiscal year end before the takeover } \\
\text { announcement. }\end{array}$ & Compustat \\
\hline Mixed & 1 for deals financed with a mix of cash and stock. & SDC \\
\hline Multiple bidders & 1 when there is more than one bidder. & SDC \\
\hline Private & 1 when the target is a private. & SDC \\
\hline Public & 1 when the target is a publicly listed company. & SDC \\
\hline Relative size & $\begin{array}{l}\text { Ratio of the deal size to the bidder market capitalization at the last fiscal year end } \\
\text { before the takeover announcement. }\end{array}$ & $\begin{array}{l}\text { Compustat, } \\
\text { SDC }\end{array}$ \\
\hline ROA & $\begin{array}{l}\text { Bidder firm return on assets [EBITDA / Book value of assets (AT)] at the last fiscal } \\
\text { year end before the takeover announcement, expressed in } \% \text {. }\end{array}$ & Compustat \\
\hline Shares & 1 for deals financed with stock only. & SDC \\
\hline Target term. fee & 1 if the target is liable to pay a termination fee to the acquirer. & SDC \\
\hline Tender offer & 1 when the deal is structured as a tender offer & SDC \\
\hline
\end{tabular}




\section{Table 3: Descriptive statistics}

This table reports summary statistics for the main variables used in our analysis. Panel A reports statistics for the announcement text variables. Panel B reports statistics for the dependent variables. Different measures of bidder and target intangible assets are presented in Panels $\mathrm{C}$ and D, respectively, followed by the control variables presented in Panel E. The sample consists of 3036 takeover deals announced between January 2002 and December 2016 with the bidder that is a publicly traded company domiciled in the United States. We require that deal and bidder data are available in SDC, CRSP and COMPUSTAT, and that the takeover announcement is accessible through EDGAR. We collect transactions with at least \$1 million deal value and 1\% relative size (deal value to bidder market capitalization ratio) and that are not labeled as as recapitalizations, repurchases, self-tenders, nor exchange offers. We require that the bidder owns at least $80 \%$ of the target after the purchase in case of completed deals, and not more than $15 \%$ before the announcement. Bidders that operate in regulated utilities (SIC code 49004999) or financial industry (SIC code 6000-6999) are excluded from the sample. \% Intangibles talk is defined as the number of intangibles words divided by the total number of words in the announcement, expressed in percent. The detailed description of the other variables is provided in Table 2.

\begin{tabular}{|c|c|c|c|c|c|}
\hline & Mean & Median & St. Dev. & $\mathrm{p} 25$ & $\mathrm{p} 75$ \\
\hline \multicolumn{6}{|l|}{ Panel A: Textual variables } \\
\hline$\%$ Intangibles talk & 2.38 & 2.30 & 1.00 & 1.65 & 3.03 \\
\hline$\%$ Negative & 0.34 & 0.28 & 0.28 & 0.16 & 0.45 \\
\hline$\%$ Positive & 1.41 & 1.35 & 0.58 & 0.99 & 1.77 \\
\hline$\%$ Strong modal & 0.19 & 0.16 & 0.12 & 0.11 & 0.24 \\
\hline$\%$ Uncertainty & 0.43 & 0.39 & 0.24 & 0.26 & 0.55 \\
\hline Negativity & -0.55 & -0.59 & 0.27 & -0.75 & -0.42 \\
\hline Text length & 890.1 & 781.5 & 492.0 & 552 & 1110 \\
\hline \multicolumn{6}{|l|}{ Panel B: Dependent variables } \\
\hline $\operatorname{CAR}(-1,1)[\%]$ & 0.48 & 0.31 & 8.17 & -3.06 & 3.78 \\
\hline $\operatorname{CAR}(-1,30)[\%]$ & -1.72 & -0.79 & 18.6 & -10.4 & 7.91 \\
\hline $\mathrm{CAR}_{\mathrm{t}}(-1,1)[\%]$ & 24.6 & 20.7 & 22.2 & 9.77 & 35.1 \\
\hline Completed & 0.93 & 1 & 0.26 & 1 & 1 \\
\hline Days to completion & 54.8 & 34 & 67.3 & 0 & 81 \\
\hline$\Delta \operatorname{ROA}(0,1)[\%]$ & 0.86 & 0.87 & 8.17 & -2.11 & 3.94 \\
\hline$\Delta \operatorname{ROA}(0,3)[\%]$ & 0.58 & 0.90 & 11.3 & -3.79 & 5.13 \\
\hline$\Delta$ Analyst recom. & 0.020 & 0 & 0.37 & 0 & 0 \\
\hline CEO buys & 0.11 & 0 & 0.31 & 0 & 0 \\
\hline Top Execs buy & 0.069 & 0 & 0.25 & 0 & 0 \\
\hline CEO or Execs buy & 0.14 & 0 & 0.35 & 0 & 0 \\
\hline Directors buy & 0.13 & 0 & 0.34 & 0 & 0 \\
\hline \multicolumn{6}{|c|}{ Panel C: Bidder intangible assets } \\
\hline$(\text { Intan. assetspt })_{\mathrm{b}}$ [USDm] & 2084.3 & 269.5 & 6997.6 & 81.7 & 953.6 \\
\hline$\left(\text { Intan. } \text { assets }_{\mathrm{bv}}\right)_{\mathrm{b}}$ [USDm] & 962.0 & 81.3 & 3300.5 & 11.7 & 404.8 \\
\hline$\left(\mathrm{IA} \mathrm{PT}_{\mathrm{PT}} / \mathrm{AT}\right)_{\mathrm{b}}$ & 0.76 & 0.68 & 0.52 & 0.45 & 0.92 \\
\hline$\left(\mathrm{IA}_{\mathrm{bv}} / \mathrm{AT}\right)_{\mathrm{b}}$ & 0.25 & 0.20 & 0.21 & 0.061 & 0.39 \\
\hline \multicolumn{6}{|c|}{ Panel D: Target intangible assets (public targets only) } \\
\hline$(\text { Intan. } \operatorname{assetspT})_{\mathrm{t}}[\mathrm{USDm}]$ & 1172.2 & 191.8 & 3981.0 & 75.7 & 664.2 \\
\hline$\left(\text { Intan. } \text { assets }_{\mathrm{bv}}\right)_{\mathrm{t}}$ [USDm] & 450.4 & 32.6 & 1347.2 & 1.76 & 232 \\
\hline$\left(\text { Intan. } \text { assets }_{\mathrm{acq}}\right)_{\mathrm{t}}[\mathrm{USDm}]$ & 1534.3 & 209.2 & 4042.5 & 27.6 & 1148.5 \\
\hline$\left(\mathrm{IA}_{\mathrm{PT}} / \mathrm{AT}\right)_{\mathrm{t}}$ & 0.92 & 0.72 & 0.93 & 0.42 & 1.07 \\
\hline$\left(\mathrm{IA}_{\mathrm{bv}} / \mathrm{AT}\right)_{\mathrm{t}}$ & 0.19 & 0.13 & 0.20 & 0.016 & 0.31 \\
\hline$\left(\mathrm{IA}_{\mathrm{acq}} / \mathrm{AT}\right)_{\mathrm{t}}$ & 1.56 & 0.84 & 2.29 & 0.18 & 1.86 \\
\hline \multicolumn{6}{|l|}{ Panel E: Control variables } \\
\hline Acquirer term. fee & 0.096 & 0 & 0.29 & 0 & 0 \\
\hline Cash & 0.59 & 1 & 0.49 & 0 & 1 \\
\hline Cross-country & 0.16 & 0 & 0.37 & 0 & 0 \\
\hline Cross-industry & 0.36 & 0 & 0.48 & 0 & 1 \\
\hline Deal size [USDm] & 719.5 & 74.6 & 2475.2 & 21.9 & 300 \\
\hline Friendly & 0.98 & 1 & 0.15 & 1 & 1 \\
\hline High-tech & 0.42 & 0 & 0.49 & 0 & 1 \\
\hline Market cap [USDm] & 4712.2 & 700.4 & 15049.4 & 202.8 & 2233.9 \\
\hline Market-to-book & 3.42 & 2.42 & 3.38 & 1.58 & 3.89 \\
\hline Mixed & 0.31 & 0 & 0.46 & 0 & 1 \\
\hline Multiple bidders & 0.027 & 0 & 0.16 & 0 & 0 \\
\hline Private & 0.70 & 1 & 0.46 & 0 & 1 \\
\hline Public & 0.30 & 0 & 0.46 & 0 & 1 \\
\hline Relative size & 0.29 & 0.12 & 0.48 & 0.047 & 0.31 \\
\hline $\mathrm{ROA}[\%]$ & 8.40 & $44^{1.5}$ & 16.9 & 5.58 & 16.5 \\
\hline Shares & 0.11 & ${ }^{4}+0$ & 0.31 & 0 & 0 \\
\hline Target term. fee & 0.24 & 0 & 0.43 & 0 & 0 \\
\hline Tender offer & 0.062 & 0 & 0.24 & 0 & 0 \\
\hline
\end{tabular}
3036 


\section{Table 4: What explains intangibles talk?}

This table reports OLS regression results. The dependent variable, \% Intangibles talk, is defined as the number of intangibles words divided by the total number of words in the takeover announcement, expressed in percent. Panel A reports results for the full sample (takeover announcements between January 2002 and December 2016 with the bidder that is a publicly traded company domiciled in the United States), while panel B is limited to public target deals. Financial data are not available for private targets for targets abroad. $\left(\mathrm{IA}_{\mathrm{s}} / \mathrm{AT}\right)_{\mathrm{j}}$ is the ratio of $j=[\mathrm{b}$ (idder), $\mathrm{t}($ arget $)]$ intangible assets to total assets, where $s=[\mathrm{PT}$ (Peters and Taylor), bv(book value), acq (deal size minus the book value of tangible assets)]. $\mathrm{IA}_{\mathrm{acq}}$ is only available for targets. Additional variable descriptions are provided in Table 2. The continuous variables are winsorized at the $1^{\text {st }}$ and $99^{\text {th }}$ percentiles. Each regression includes industry and year fixed effects as indicated. The standard errors (reported in parentheses) are clustered by the announcement year and are robust to heteroskedasticity. Significance levels: : * $-10 \%, * *-5 \%, * * *-1 \%$

(a) Panel A: Full sample

\begin{tabular}{lcccccc}
\hline & $(1)$ & $(2)$ & $(3)$ & $(4)$ & $(5)$ & $(6)$ \\
\hline$\left(\mathrm{IA}_{\mathrm{PT}} / \mathrm{AT}\right)_{\mathrm{b}}$ & $0.153^{* * *}$ & & -0.010 & & 0.010 & \\
& $(0.034)$ & & $(0.035)$ & & $(0.031)$ & \\
$\left(\mathrm{IA}_{\mathrm{bv}} / \mathrm{AT}\right)_{\mathrm{b}}$ & & $0.337^{* *}$ & & -0.005 & & 0.085 \\
& & $(0.126)$ & & $(0.111)$ & & $(0.092)$ \\
Relative size & & & & & $-0.317^{* * *}$ & $-0.313^{* * *}$ \\
& & & & & $(0.023)$ & $(0.022)$ \\
Public & & & & & $-0.533^{* * *}$ & $-0.539^{* * *}$ \\
& & & & & $(0.030)$ & $(0.032)$ \\
Constant & $2.208^{* * *}$ & $2.271^{* * *}$ & $1.089^{* * *}$ & $1.106^{* * *}$ & $1.312^{* * *}$ & $1.343^{* * *}$ \\
& $(0.024)$ & $(0.024)$ & $(0.214)$ & $(0.217)$ & $(0.256)$ & $(0.257)$ \\
Year FE & Yes & Yes & Yes & Yes & Yes & Yes \\
Industry FE & No & No & Yes & Yes & Yes & Yes \\
\hline Adjusted $R^{2}$ & 0.01 & 0.00 & 0.22 & 0.21 & 0.31 & 0.31 \\
Observations & 3036 & 3023 & 3036 & 3023 & 3036 & 3023 \\
\hline
\end{tabular}

(b) Panel B: Public targets: The role of target intangible assets

\begin{tabular}{|c|c|c|c|c|c|c|c|c|c|}
\hline & \multicolumn{3}{|c|}{ PT(2017) IA measures } & \multicolumn{3}{|c|}{ Book value IA measures } & \multicolumn{3}{|c|}{ Acquired IA measures } \\
\hline & (1) & (2) & (3) & (4) & (5) & (6) & (7) & (8) & (9) \\
\hline$\left(\mathrm{IA}_{\mathrm{PT}} / \mathrm{AT}\right)_{\mathrm{b}}$ & $\begin{array}{c}0.235^{* * *} \\
(0.068)\end{array}$ & $\begin{array}{c}0.188^{* * *} \\
(0.062)\end{array}$ & $\begin{array}{c}0.053 \\
(0.078)\end{array}$ & & & & $\begin{array}{c}0.235^{* * *} \\
(0.068)\end{array}$ & $\begin{array}{c}0.218^{* * *} \\
(0.061)\end{array}$ & $\begin{array}{c}0.045 \\
(0.073)\end{array}$ \\
\hline$\left(\mathrm{IA}_{\mathrm{bv}} / \mathrm{AT}\right)_{\mathrm{b}}$ & & & & $\begin{array}{c}0.427^{* * *} \\
(0.138)\end{array}$ & $\begin{array}{l}0.316^{* *} \\
(0.146)\end{array}$ & $\begin{array}{c}0.106 \\
(0.175)\end{array}$ & & & \\
\hline$\left(\mathrm{IA} \mathrm{PT}_{\mathrm{PT}} / \mathrm{AT}\right)_{\mathrm{t}}$ & & $\begin{array}{c}0.036 \\
(0.029)\end{array}$ & $\begin{array}{l}-0.005 \\
(0.026)\end{array}$ & & & & & & \\
\hline$\left(\mathrm{IA}_{\mathrm{bv}} / \mathrm{AT}\right)_{\mathrm{t}}$ & & & & & $\begin{array}{c}0.131 \\
(0.100)\end{array}$ & $\begin{array}{l}-0.031 \\
(0.100)\end{array}$ & & & \\
\hline$\left(\mathrm{IA}_{\mathrm{acq}} / \mathrm{AT}\right)_{\mathrm{t}}$ & & & & & & & & $\begin{array}{c}0.004 \\
(0.014)\end{array}$ & $\begin{array}{c}0.001 \\
(0.009)\end{array}$ \\
\hline Relative size & & & $\begin{array}{c}-0.174^{* * *} \\
(0.032)\end{array}$ & & & $\begin{array}{c}-0.172^{* * *} \\
(0.034)\end{array}$ & & & $\begin{array}{c}-0.172^{* * *} \\
(0.031)\end{array}$ \\
\hline Constant & $\begin{array}{c}1.930^{* * *} \\
(0.044)\end{array}$ & $\begin{array}{c}1.887^{* * *} \\
(0.037)\end{array}$ & $\begin{array}{c}1.376^{* * *} \\
(0.061)\end{array}$ & $\begin{array}{c}2.034^{* * *} \\
(0.028)\end{array}$ & $\begin{array}{c}2.008^{* * *} \\
(0.021)\end{array}$ & $\begin{array}{c}1.450^{* * *} \\
(0.029)\end{array}$ & $\begin{array}{c}1.930^{* * *} \\
(0.044)\end{array}$ & $\begin{array}{c}1.890^{* * *} \\
(0.035)\end{array}$ & $\begin{array}{c}1.381^{* * *} \\
(0.059)\end{array}$ \\
\hline Year FE & Yes & Yes & Yes & Yes & Yes & Yes & Yes & Yes & Yes \\
\hline Industry FE & No & No & Yes & No & No & Yes & No & No & Yes \\
\hline Adjusted $R^{2}$ & 0.03 & 0.02 & 0.27 & 0.02 & 0.01 & 0.26 & 0.03 & 0.02 & 0.27 \\
\hline Observations & 913 & 672 & 672 & 903 & 672 & 672 & 913 & 677 & 677 \\
\hline
\end{tabular}




\section{Table 5: Deal completion}

This table reports the analysis of the relation between intangibles talk and deal completion. The first two specifications report results of probit regressions estimating the propensity for the bidder to complete the deal following the takeover announcement. The last two specifications report OLS regression results for the number of days it takes to complete the deal, given that the bidder acquires the target. The sample consists of takeover deals announced between January 2002 and December 2016 with the bidder that is a publicly traded company domiciled in the United States. $\%$ Intangibles talk is defined as the number of intangibles words divided by the total number of words in the announcement, expressed as a percent. Additional variable descriptions are provided in Table 2. Days to completion and continuous control variables are winsorized at the $1^{\text {st }}$ and $99^{\text {th }}$ percentile. The first two specifications report average marginal effects instead of estimated coefficients. The standard errors (reported in parentheses) are clustered by the announcement year and are robust to heteroskedasticity. Significance levels: : * - 10\%, ** - 5\%, *** - 1\%

\begin{tabular}{|c|c|c|c|c|}
\hline & \multicolumn{2}{|c|}{ Completion } & \multicolumn{2}{|c|}{ Days to completion } \\
\hline & (1) & (2) & (3) & (4) \\
\hline$\%$ Intangibles talk & $\begin{array}{c}0.023^{* * *} \\
(0.006)\end{array}$ & $\begin{array}{c}0.016^{* * *} \\
(0.005)\end{array}$ & $\begin{array}{l}-4.091^{* *} \\
(1.442)\end{array}$ & $\begin{array}{l}-3.204^{*} \\
(1.542)\end{array}$ \\
\hline Negativity & & $\begin{array}{c}-0.029^{* *} \\
(0.014)\end{array}$ & & $\begin{array}{l}7.826^{* *} \\
(3.281)\end{array}$ \\
\hline$\%$ Uncertainty & & $\begin{array}{c}-0.042^{* * *} \\
(0.014)\end{array}$ & & $\begin{array}{l}1.087 \\
(4.725)\end{array}$ \\
\hline$\%$ Strong modal & & $\begin{array}{l}-0.020 \\
(0.038)\end{array}$ & & $\begin{array}{c}0.304 \\
(7.849)\end{array}$ \\
\hline Public & $\begin{array}{c}-0.094^{* * *} \\
(0.025)\end{array}$ & $\begin{array}{c}-0.095^{* * *} \\
(0.024)\end{array}$ & $\begin{array}{c}44.959^{* * *} \\
(6.186)\end{array}$ & $\begin{array}{c}45.238^{* * *} \\
(6.214)\end{array}$ \\
\hline Mixed & $\begin{array}{l}-0.002 \\
(0.011)\end{array}$ & $\begin{array}{l}-0.003 \\
(0.011)\end{array}$ & $\begin{array}{c}11.479^{* * *} \\
(3.340)\end{array}$ & $\begin{array}{c}11.854^{* * *} \\
(3.404)\end{array}$ \\
\hline Shares & $\begin{array}{c}-0.039^{* *} \\
(0.018)\end{array}$ & $\begin{array}{c}-0.045^{* * *} \\
(0.018)\end{array}$ & $\begin{array}{c}38.264^{* * *} \\
(3.158)\end{array}$ & $\begin{array}{c}38.573^{* * *} \\
(3.227)\end{array}$ \\
\hline $\operatorname{CAR}(-1,1)[\%]$ & $\begin{array}{c}0.001 \\
(0.000)\end{array}$ & $\begin{array}{c}0.000 \\
(0.000)\end{array}$ & $\begin{array}{c}0.038 \\
(0.147)\end{array}$ & $\begin{array}{c}0.043 \\
(0.148)\end{array}$ \\
\hline Relative size & $\begin{array}{l}-0.016^{*} \\
(0.009)\end{array}$ & $\begin{array}{l}-0.016^{*} \\
(0.009)\end{array}$ & $\begin{array}{c}35.362^{* * *} \\
(3.858)\end{array}$ & $\begin{array}{c}35.439^{* * *} \\
(3.831)\end{array}$ \\
\hline Cross-industry & $\begin{array}{c}0.005 \\
(0.012)\end{array}$ & $\begin{array}{c}0.006 \\
(0.012)\end{array}$ & $\begin{array}{l}-0.254 \\
(3.029)\end{array}$ & $\begin{array}{l}-0.229 \\
(3.022)\end{array}$ \\
\hline Cross-country & $\begin{array}{l}-0.010 \\
(0.012)\end{array}$ & $\begin{array}{l}-0.013 \\
(0.012)\end{array}$ & $\begin{array}{l}4.587^{*} \\
(2.525)\end{array}$ & $\begin{array}{l}4.898^{*} \\
(2.513)\end{array}$ \\
\hline Tender offer & $\begin{array}{c}0.051^{* * *} \\
(0.007)\end{array}$ & $\begin{array}{c}0.050^{* * *} \\
(0.007)\end{array}$ & $\begin{array}{c}-27.574^{* * *} \\
(5.724)\end{array}$ & $\begin{array}{c}-27.831^{* * *} \\
(5.550)\end{array}$ \\
\hline Multiple bidders & $\begin{array}{c}-0.323^{* * *} \\
(0.072)\end{array}$ & $\begin{array}{c}-0.313^{* * *} \\
(0.072)\end{array}$ & $\begin{array}{c}13.955 \\
(16.872)\end{array}$ & $\begin{array}{c}13.541 \\
(16.927)\end{array}$ \\
\hline Friendly & $\begin{array}{c}0.385^{* * *} \\
(0.082)\end{array}$ & $\begin{array}{c}0.367^{* * *} \\
(0.078)\end{array}$ & $\begin{array}{c}-9.775 \\
(17.674)\end{array}$ & $\begin{array}{c}-9.804 \\
(17.474)\end{array}$ \\
\hline Target term. fee & $\begin{array}{c}0.063^{* * *} \\
(0.009)\end{array}$ & $\begin{array}{c}0.063^{* * *} \\
(0.008)\end{array}$ & $\begin{array}{l}9.779^{*} \\
(4.876)\end{array}$ & $\begin{array}{l}9.849^{*} \\
(4.909)\end{array}$ \\
\hline Acquirer term. fee & $\begin{array}{c}-0.028^{* *} \\
(0.013)\end{array}$ & $\begin{array}{c}-0.028^{* *} \\
(0.013)\end{array}$ & $\begin{array}{c}22.445^{* * *} \\
(4.534)\end{array}$ & $\begin{array}{c}22.416^{* * *} \\
(4.553)\end{array}$ \\
\hline $\ln$ (Text length) & $\begin{array}{l}0.025^{* *} \\
(0.010)\end{array}$ & $\begin{array}{c}0.013 \\
(0.009)\end{array}$ & $\begin{array}{c}0.549 \\
(2.506)\end{array}$ & $\begin{array}{l}1.266 \\
(2.812)\end{array}$ \\
\hline$\left(\mathrm{IA} \mathrm{PT}_{\mathrm{PT}} / \mathrm{AT}\right)_{\mathrm{b}}$ & $\begin{array}{c}0.004 \\
(0.007)\end{array}$ & $\begin{array}{c}0.004 \\
(0.007)\end{array}$ & $\begin{array}{l}-5.131 \\
(3.339)\end{array}$ & $\begin{array}{l}-5.139 \\
(3.385)\end{array}$ \\
\hline $\mathrm{ROA}[\%]$ & $\begin{array}{l}0.001^{* *} \\
(0.000)\end{array}$ & $\begin{array}{l}0.000^{* *} \\
(0.000)\end{array}$ & $\begin{array}{l}-0.120 \\
(0.128)\end{array}$ & $\begin{array}{l}-0.107 \\
(0.129)\end{array}$ \\
\hline $\ln$ (Market cap) & $\begin{array}{c}0.004 \\
(0.003)\end{array}$ & $\begin{array}{c}0.004 \\
(0.003)\end{array}$ & $\begin{array}{c}5.501^{* * *} \\
(1.065)\end{array}$ & $\begin{array}{c}5.492^{* * *} \\
(1.089)\end{array}$ \\
\hline Market-to-book & $\begin{array}{c}-0.003^{* * *} \\
(0.001)\end{array}$ & $\begin{array}{c}-0.003^{* * *} \\
(0.001)\end{array}$ & $\begin{array}{c}0.258 \\
(0.364)\end{array}$ & $\begin{array}{c}0.253 \\
(0.364)\end{array}$ \\
\hline Constant & & & $\begin{array}{c}10.373 \\
(30.771)\end{array}$ & $\begin{array}{c}5.039 \\
(29.950)\end{array}$ \\
\hline Year FE & Yes & Yes & Yes & Yes \\
\hline Industry FE & Yes & Yes & Yes & Yes \\
\hline $\begin{array}{l}\text { Adjusted } R^{2} \\
\text { Pseudo } R^{2}\end{array}$ & 0.29 & & 0.46 & 0.46 \\
\hline Observations & 3036 & 3036 & 2814 & 2814 \\
\hline
\end{tabular}




\section{Table 6: Abnormal bidder returns}

This table reports OLS regression results for the bidder's cumulative abnormal returns, CAR(-1,1) and CAR($1,30)$, measured using Carhart four-factor model returns. The sample consists of takeover announcements between January 2002 and December 2016 with the bidder that is a publicly traded company domiciled in the United States. \% Intangibles talk is defined as the number of intangibles words divided by the total number of words in the announcement, expressed as a percent. Additional variable descriptions are provided in Table 2 . The dependent variables $(\mathrm{CAR}(-1,1)$ and $\mathrm{CAR}(-1,30))$ and continuous control variables are winsorized at the $1^{\text {st }}$ and $99^{\text {th }}$ percentile. The standard errors (reported in parentheses) are clustered by the announcement year and are robust to heteroskedasticity. Significance levels: : * - 10\%, ** - 5\%,***-1\%

\begin{tabular}{|c|c|c|c|c|}
\hline & $\begin{array}{c}(1) \\
\operatorname{CAR}(-1,1)[\%]\end{array}$ & $\begin{array}{c}(2) \\
\text { CAR }(-1,1)[\%]\end{array}$ & $\begin{array}{c}(3) \\
\operatorname{CAR}(-1,30)[\%]\end{array}$ & $\begin{array}{c}(4) \\
\text { CAR }(-1,30)[\%]\end{array}$ \\
\hline$\%$ Intangibles talk & $\begin{array}{c}-0.373^{* * *} \\
(0.121)\end{array}$ & $\begin{array}{c}-0.454^{* * *} \\
(0.135)\end{array}$ & $\begin{array}{c}-0.846^{* *} \\
(0.337)\end{array}$ & $\begin{array}{l}-0.909^{* *} \\
(0.352)\end{array}$ \\
\hline Negativity & & $\begin{array}{l}-1.176^{*} \\
(0.564)\end{array}$ & & $\begin{array}{l}-0.336 \\
(1.200)\end{array}$ \\
\hline$\%$ Uncertainty & & $\begin{array}{l}1.203 \\
(0.687)\end{array}$ & & $\begin{array}{l}-0.503 \\
(1.525)\end{array}$ \\
\hline$\%$ Strong modal & & $\begin{array}{l}-0.360 \\
(1.117)\end{array}$ & & $\begin{array}{c}4.494 \\
(3.220)\end{array}$ \\
\hline Public & $\begin{array}{c}-2.565^{* * *} \\
(0.765)\end{array}$ & $\begin{array}{c}-2.604^{* * *} \\
(0.769)\end{array}$ & $\begin{array}{l}-3.146^{* *} \\
(1.167)\end{array}$ & $\begin{array}{l}-3.144^{* *} \\
(1.166)\end{array}$ \\
\hline Mixed & $\begin{array}{l}-0.492 \\
(0.329)\end{array}$ & $\begin{array}{l}-0.529 \\
(0.338)\end{array}$ & $\begin{array}{l}-0.492 \\
(0.782)\end{array}$ & $\begin{array}{l}-0.527 \\
(0.811)\end{array}$ \\
\hline Shares & $\begin{array}{c}-1.012 \\
(0.788)\end{array}$ & $\begin{array}{l}-1.005 \\
(0.794)\end{array}$ & $\begin{array}{l}-2.645^{*} \\
(1.291)\end{array}$ & $\begin{array}{l}-2.720^{*} \\
(1.316)\end{array}$ \\
\hline Relative size & $\begin{array}{l}1.238^{* *} \\
(0.522)\end{array}$ & $\begin{array}{l}1.192^{* *} \\
(0.535)\end{array}$ & $\begin{array}{c}0.496 \\
(1.090)\end{array}$ & $\begin{array}{c}0.515 \\
(1.085)\end{array}$ \\
\hline Cross-industry & $\begin{array}{l}-0.329 \\
(0.347)\end{array}$ & $\begin{array}{l}-0.327 \\
(0.349)\end{array}$ & $\begin{array}{l}-0.430 \\
(0.709)\end{array}$ & $\begin{array}{l}-0.426 \\
(0.704)\end{array}$ \\
\hline Cross-country & $\begin{array}{c}0.309 \\
(0.413)\end{array}$ & $\begin{array}{c}0.288 \\
(0.420)\end{array}$ & $\begin{array}{c}0.553 \\
(0.990)\end{array}$ & $\begin{array}{c}0.595 \\
(0.994)\end{array}$ \\
\hline Tender offer & $\begin{array}{l}1.856^{* *} \\
(0.776)\end{array}$ & $\begin{array}{l}1.942^{* *} \\
(0.796)\end{array}$ & $\begin{array}{l}3.189^{*} \\
(1.488)\end{array}$ & $\begin{array}{l}3.246^{* *} \\
(1.445)\end{array}$ \\
\hline Multiple bidders & $\begin{array}{l}-0.659 \\
(1.409)\end{array}$ & $\begin{array}{l}-0.641 \\
(1.416)\end{array}$ & $\begin{array}{c}0.150 \\
(2.266)\end{array}$ & $\begin{array}{c}0.117 \\
(2.276)\end{array}$ \\
\hline Friendly & $\begin{array}{l}-0.922 \\
(0.850)\end{array}$ & $\begin{array}{l}-0.939 \\
(0.821)\end{array}$ & $\begin{array}{l}4.117 \\
(2.840)\end{array}$ & $\begin{array}{l}4.206 \\
(2.765)\end{array}$ \\
\hline $\ln ($ Text length) & $\begin{array}{l}-0.753^{*} \\
(0.362)\end{array}$ & $\begin{array}{l}-0.697 \\
(0.403)\end{array}$ & $\begin{array}{l}-1.640^{*} \\
(0.816)\end{array}$ & $\begin{array}{l}-1.281 \\
(0.893)\end{array}$ \\
\hline$\left(\mathrm{IA}_{\mathrm{PT}} / \mathrm{AT}\right)_{\mathrm{b}}$ & $\begin{array}{l}-0.276 \\
(0.489)\end{array}$ & $\begin{array}{l}-0.261 \\
(0.486)\end{array}$ & $\begin{array}{l}-1.700 \\
(1.577)\end{array}$ & $\begin{array}{l}-1.719 \\
(1.587)\end{array}$ \\
\hline $\mathrm{ROA}[\%]$ & $\begin{array}{l}-0.010 \\
(0.014)\end{array}$ & $\begin{array}{l}-0.012 \\
(0.014)\end{array}$ & $\begin{array}{c}0.050 \\
(0.034)\end{array}$ & $\begin{array}{c}0.049 \\
(0.035)\end{array}$ \\
\hline $\ln ($ Market cap) & $\begin{array}{c}-0.320^{* *} \\
(0.122)\end{array}$ & $\begin{array}{l}-0.318^{* *} \\
(0.123)\end{array}$ & $\begin{array}{l}-0.091 \\
(0.259)\end{array}$ & $\begin{array}{l}-0.107 \\
(0.261)\end{array}$ \\
\hline Market-to-book & $\begin{array}{c}0.066 \\
(0.052)\end{array}$ & $\begin{array}{c}0.067 \\
(0.051)\end{array}$ & $\begin{array}{l}-0.273 \\
(0.181)\end{array}$ & $\begin{array}{l}-0.272 \\
(0.181)\end{array}$ \\
\hline Constant & $\begin{array}{c}22.745^{* * *} \\
(3.082)\end{array}$ & $\begin{array}{c}22.582^{* * *} \\
(3.720)\end{array}$ & $\begin{array}{l}38.290^{* * *} \\
(9.934)\end{array}$ & $\begin{array}{c}36.151^{* * *} \\
(9.978)\end{array}$ \\
\hline Year FE & Yes & Yes & Yes & Yes \\
\hline Industry FE & Yes & Yes & Yes & Yes \\
\hline $\begin{array}{l}\text { Adjusted } R^{2} \\
\text { Observations }\end{array}$ & $\begin{array}{c}0.04 \\
3036\end{array}$ & $\begin{array}{l}0.05 \\
3036\end{array}$ & $\begin{array}{c}0.02 \\
3036\end{array}$ & $\begin{array}{l}0.02 \\
3036\end{array}$ \\
\hline
\end{tabular}




\section{Table 7: Ex-post performance and analyst stock recommendations}

The table reports OLS regression results for changes in the bidder performance ( $\triangle \mathrm{ROA})$ and analyst stock recommendation changes ( $\Delta$ Analyst recom.) following the acquisition. The sample consists of completed takeover deals announced between January 2002 and December 2016 with the bidder that is a publicly traded company domiciled in the United States. The first specification reports results for changes in ROA from year 0 to year 1 , where year 0 is defined as the year of acquisition. The second specification reports results for a 3-year period. We adjust bidder ROA changes by subtracting those of the bidder's industry peers. For each bidder, we construct a portfolio of peers that do not differ more than $50 \%$ in size from the bidder, operate in the same 2-digit SIC industry, and are not involved in any acquisition during a six-year period surrounding the transaction. The benchmark is calculated as a mean performance change of each portfolio. The third specification reports results for changes in the analyst recommendations, calculated as the difference between the earliest available median recommendation that is calculated within the 7-60 days period after the takeover announcement and the most recent median recommendation calculated within the 7-60 days period before the takeover announcement. Thomson Reuters calculates median recommendations by assigning to each contributing analyst's recommendation an integer based on the standardized Thomson Reuters recommendation scale and calculating a real number median. We construct and use the inversed scale as follows: 5. Strong Buy, 4. Buy, 3. Hold, 2. Underperform, 1. Sell. \% Intangibles talk is defined as the number of intangibles words divided by the total number of words in the announcement, expressed as a percent. Additional variable descriptions are provided in Table 2. All regressions include the control variables included in Table 6. The dependent variables and continuous control variables are winsorized at the $1^{\text {st }}$ and $99^{\text {th }}$ percentiles. The standard errors (reported in parentheses) are clustered by the announcement year and are robust to heteroskedasticity. Significance levels: : * - 10\%,**-5\%,***-1\%

\begin{tabular}{|c|c|c|c|}
\hline & $\Delta \operatorname{ROA}(0,1$ year $)$ & $\Delta \operatorname{ROA}(0,3$ years $)$ & $\Delta$ Analyst recom. \\
\hline & (1) & (2) & (3) \\
\hline$\%$ Intangibles talk & $\begin{array}{c}-0.452^{* *} \\
(0.197)\end{array}$ & $\begin{array}{c}-0.296 \\
(0.443)\end{array}$ & $\begin{array}{c}-0.015^{* *} \\
(0.007)\end{array}$ \\
\hline Controls & Yes & Yes & Yes \\
\hline Textual variables & Yes & Yes & Yes \\
\hline Year FE & Yes & Yes & Yes \\
\hline Industry FE & Yes & Yes & Yes \\
\hline Adjusted $R^{2}$ & 0.04 & 0.03 & 0.01 \\
\hline Observations & 2320 & 1661 & 2703 \\
\hline
\end{tabular}




\section{Table 8: Corporate governance and intangibles talk}

The table reports the effect of intangibles talk on bidder returns and deal completion conditional on the quality of corporate governance of the bidder. The sample consists of the takeovers announced between January 2002 and December 2016 with the bidder that is a publicly traded company domiciled in the United States. In Panel A, we summarize OLS regression results for bidder cumulative abnormal returns, CAR(-1,1), measured using Carhart four-factor model. In Panel B, we report the results from OLS regression results for days to completion. \% Intangibles talk is defined as the number of intangibles words divided by the total number of words in the announcement, expressed as a percent. We interact intangibles talk with measures of poor corporate governance, Low executive incentives and Low institutional stake. Additional variable descriptions are provided in Table 2. All regressions include the control variables included in Table 6. CAR and continuous control variables are winsorized at the $1^{\text {st }}$ and $99^{\text {th }}$ percentiles. The standard errors (reported in parentheses) are clustered by the announcement year and are robust to heteroskedasticity. Significance levels: : * $-10 \%, * *-5 \%, * * *-1 \%$

(a) Panel A: Bidder CAR

\begin{tabular}{lcccc}
\hline & $(1)$ & $(2)$ & $(3)$ & $(4)$ \\
\hline \% Intangibles talk & $-0.628^{* * *}$ & $-0.711^{* * *}$ & -0.456 & -0.520 \\
& $(0.175)$ & $(0.179)$ & $(0.300)$ & $(0.312)$ \\
Low inst. stake & 0.366 & 0.384 & & \\
& $(0.371)$ & $(0.365)$ & & \\
Low inst. stake $\times \%$ Intangibles talk & $0.462^{*}$ & $0.447^{*}$ & & \\
& $(0.242)$ & $(0.240)$ & & \\
Low executive incentives & & & $-1.184^{* *}$ & $-1.193^{* *}$ \\
& & & $(0.429)$ & $(0.431)$ \\
Low executive incentives $\times \%$ Intangibles talk & & & -0.369 & -0.376 \\
& & & $(0.302)$ & $(0.306)$ \\
Textual variables & No & Yes & No & Yes \\
Controls & Yes & Yes & Yes & Yes \\
Year FE & Yes & Yes & Yes & Yes \\
Industry FE & Yes & Yes & Yes & Yes \\
\hline Adjusted $R^{2}$ & 0.05 & 0.05 & 0.07 & 0.07 \\
Observations & 3047 & 3047 & 1457 & 1457 \\
\hline
\end{tabular}

(b) Panel B: Days to completion

\begin{tabular}{lcccc}
\hline & $(1)$ & $(2)$ & $(3)$ & $(4)$ \\
\hline \% Intangibles talk & -0.194 & 0.758 & 0.855 & -0.520 \\
& $(2.088)$ & $(2.214)$ & $(2.540)$ & $(0.312)$ \\
Low inst. stake & $4.167^{* *}$ & $4.180^{* *}$ & & \\
& $(1.845)$ & $(1.759)$ & & \\
Low inst. stake $\times$ \% Intangibles talk & $-6.993^{* * *}$ & $-7.102^{* * *}$ & & \\
& $(2.014)$ & $(1.997)$ & & \\
Low executive incentives & & & 3.951 & $-1.193^{* *}$ \\
& & & $(2.718)$ & $(0.431)$ \\
Low executive incentives $\times$ \% Intangibles talk & & & -3.015 & -0.376 \\
& & & $(2.663)$ & $(0.306)$ \\
Textual variables & No & Yes & No & Yes \\
Controls & Yes & Yes & Yes & Yes \\
Year FE & Yes & Yes & Yes & Yes \\
Industry FE & Yes & Yes & Yes & Yes \\
\hline Adjusted $R^{2}$ & 0.46 & 0.46 & 0.50 & 0.07 \\
Observations & 2819 & 2819 & 1363 & 1457 \\
\hline
\end{tabular}




\section{Table 9: Payment method}

This table reports the analysis of the relation between intangibles talk and payment method choice. The table reports results of probit regressions. The dependent variable is Cash, a binary indicator which is 1 for deals financed with cash only. Column (1) and (4) use the full sample, Columns (2)-(3) and (5)-(6) only public targets. The sample consists of takeover deals announced between January 2002 and December 2016 with the bidder that is a publicly traded company domiciled in the United States. \% Intangibles talk is defined as the number of intangibles words divided by the total number of words in the announcement, expressed as a percent. Additional variable descriptions are provided in Table 2. The continuous control variables are winsorized at the $1^{\text {st }}$ and $99^{\text {th }}$ percentile. The table reports average marginal effects. The standard errors (reported in parentheses) are clustered by the announcement year and are robust to heteroskedasticity. Significance levels: : * - 10\%, **-5\%,***-1\%

\begin{tabular}{lcccccc}
\hline & $\begin{array}{c}\text { All } \\
(1)\end{array}$ & $\begin{array}{c}\text { Public targets } \\
(2)\end{array}$ & $\begin{array}{c}\text { Public targets } \\
(3)\end{array}$ & $\begin{array}{c}\text { All } \\
(4)\end{array}$ & $\begin{array}{c}\text { Public targets } \\
(5)\end{array}$ & $\begin{array}{c}\text { Public targets } \\
(6)\end{array}$ \\
\hline \% Intangibles talk & $0.091^{* * *}$ & $0.102^{* * *}$ & $0.082^{* * *}$ & $0.041^{* * *}$ & $0.066^{* * *}$ & $0.067^{* * *}$ \\
& $(0.010)$ & $(0.016)$ & $(0.015)$ & $(0.010)$ & $(0.019)$ & $(0.019)$ \\
$\left(\mathrm{IA} \mathrm{PT}_{\mathrm{PT}} / \mathrm{AT}\right)_{\mathrm{b}}$ & $-0.180^{* * *}$ & & & $-0.054^{* * *}$ & & \\
& $(0.017)$ & & & $(0.017)$ & & \\
$\left(\mathrm{IA} \mathrm{APT}_{\mathrm{t}} / \mathrm{IA} \mathrm{APT}_{\mathrm{b}}\right)$ & & $-0.099^{* * *}$ & & & 0.001 & \\
& & $(0.033)$ & & & $(0.021)$ & \\
$\left(\ln \left(\mathrm{I} \mathrm{A}_{\mathrm{PT}}\right)_{\mathrm{t}}\right) / \mathrm{ln}\left(\mathrm{IA} \mathrm{APT}_{\mathrm{b}}\right)$ & & & $-0.668^{* * *}$ & & & -0.164 \\
& & & $(0.065)$ & & & $(0.115)$ \\
Textual variables & No & No & No & Yes & Yes & Yes \\
Controls & Yes & No & No & Yes & Yes & Yes \\
Year FE & Yes & Yes & Yes & Yes & Yes & Yes \\
Industry FE & Yes & Yes & Yes & Yes & Yes & Yes \\
\hline Pseudo $R^{2}$ & 0.11 & 0.21 & 0.25 & 0.25 & 0.41 & 0.41 \\
Observations & 3036 & 674 & 674 & 3036 & 674 & 674 \\
\hline
\end{tabular}




\section{Table 10: Insider trading and intangibles talk}

The table reports results of probit regressions that estimate the propensity for the acquirer CEO, top executives, and board members to buy stock following the takeover announcement. The sample consists of the takeovers announced between January 2002 and December 2016 with the bidder that is a publicly traded company domiciled in the United States. We calculate the total number of shares traded by the CEO, Top Executives and Board members during the period 2-60 days after the takeover announcement. If the CEO (Panel A) or the CEO or the group of other top executives in aggregate (Panel B) or the group of directors in aggregate (Panel C) has a positive total number of shares traded, we classify the trade as a buy. \% Intangibles talk is defined as the number of intangibles words divided by the total number of words in the announcement, expressed as a percent. Additional variable descriptions are provided in Table 2. The table reports average marginal effects. The standard errors (reported in parentheses) are clustered by the announcement year and are robust to heteroskedasticity. Significance levels: : * $-10 \%, * *-5 \%, * * *-1 \%$

(a) Panel A: CEO

\begin{tabular}{lccc}
\hline & $(1)$ & $(2)$ & $(3)$ \\
\hline \% Intangibles talk & $0.019^{* * *}$ & $0.019^{* * *}$ & 0.008 \\
& $(0.007)$ & $(0.005)$ & $(0.010)$ \\
CAR(-1,1) [\%] & & $-0.002^{* *}$ & $-0.003^{* * *}$ \\
& & $(0.001)$ & $(0.000)$ \\
Textual variables & No & No & Yes \\
Controls & No & No & Yes \\
Year FE & Yes & Yes & Yes \\
Industry FE & Yes & Yes & Yes \\
\hline Pseudo $R^{2}$ & 0.06 & 0.06 & 0.15 \\
Observations & 3036 & 3036 & 3036 \\
\hline
\end{tabular}

(b) Panel B: CEO and Executives

\begin{tabular}{lccc}
\hline & $(1)$ & $(2)$ & $(3)$ \\
\hline \% Intangibles talk & $0.026^{* * *}$ & $0.026^{* * *}$ & $0.017^{*}$ \\
& $(0.006)$ & $(0.006)$ & $(0.009)$ \\
CAR(-1,1) [\%] & & $-0.002^{* *}$ & $-0.003^{* * *}$ \\
& & $(0.001)$ & $(0.001)$ \\
Textual variables & No & No & Yes \\
Controls & No & No & Yes \\
Year FE & Yes & Yes & Yes \\
Industry FE & Yes & Yes & Yes \\
\hline Pseudo $R^{2}$ & 0.06 & 0.06 & 0.15 \\
Observations & 3036 & 3036 & 3036 \\
\hline
\end{tabular}

(c) Panel C: Directors

\begin{tabular}{lccc}
\hline & $(1)$ & $(2)$ & $(3)$ \\
\hline \% Intangibles talk & 0.009 & 0.010 & -0.000 \\
& $(0.007)$ & $(0.007)$ & $(0.008)$ \\
CAR(-1,1) [\%] & & $-0.003^{* * *}$ & $-0.004^{* * *}$ \\
& & $(0.001)$ & $(0.001)$ \\
Textual variables & No & No & Yes \\
Controls & No & No & Yes \\
Year FE & Yes & Yes & Yes \\
Industry FE & Yes & Yes & Yes \\
\hline Pseudo $R^{2}$ & 0.05 & 0.06 & 0.11 \\
Observations & 30361 & 3036 & 3036 \\
\hline
\end{tabular}




\section{Table 11: Deal characteristics and intangibles talk}

The table reports the effect of intangibles talk on bidder returns depending on deal characteristics. The sample consists of the takeovers announced between January 2002 and December 2016 with the bidder that is a publicly traded company domiciled in the United States. We report cross-sectional regression results for bidder cumulative abnormal returns, CAR(-1,1), measured using the Carhart four-factor model. In Panel B, we report the results from OLS regression results for days to completion. We interact intangibles talk with measures of deal and bidder characteristics, Public, High-tech, and High IA industry. Public indicates a publicly listed target. High-tech denotes bidders that operate in an industry that is classified as High-tech, as in Baginski et al. (2004). High IA industry indicates bidders that operate in an industry that has above-median intangible asset intensity, defined as $\left(\mathrm{IA}_{\mathrm{PT}} / \mathrm{AT}\right)_{\mathrm{b}}$. Columns (1), (4), and (5) use the full sample. Column (2) shows results for deals above median size, Column (3) shows results for deals below median size. \% Intangibles talk is defined as the number of intangibles words divided by the total number of words in the announcement, expressed as a percent. Additional variable descriptions are provided in Table 2. CAR and continuous control variables are winsorized at the $1^{\text {st }}$ and $99^{\text {th }}$ percentiles. The standard errors (reported in parentheses) are clustered by the announcement year and are robust to heteroskedasticity. Significance levels: : * - 10\%,**-5\%,***-1\%

\begin{tabular}{|c|c|c|c|c|c|}
\hline & & Large deals & Small deals & & \\
\hline & (1) & (2) & (3) & (4) & (5) \\
\hline$\%$ Intangibles talk & $\begin{array}{c}-0.387^{* *} \\
(0.153)\end{array}$ & $\begin{array}{l}-0.862^{* * *} \\
(0.265)\end{array}$ & $\begin{array}{l}-0.210 \\
(0.211)\end{array}$ & $\begin{array}{c}-0.557^{* *} \\
(0.199)\end{array}$ & $\begin{array}{c}-0.900^{* * *} \\
(0.169)\end{array}$ \\
\hline Public & $\begin{array}{c}-2.737^{* * *} \\
(0.759)\end{array}$ & $\begin{array}{c}-2.495^{* * *} \\
(0.748)\end{array}$ & $\begin{array}{c}-3.653^{* * *} \\
(0.963)\end{array}$ & $\begin{array}{c}-2.696^{* * *} \\
(0.750)\end{array}$ & $\begin{array}{c}-2.739^{* * *} \\
(0.741)\end{array}$ \\
\hline Public $\times \%$ Intangibles talk & $\begin{array}{l}-0.424 \\
(0.339)\end{array}$ & $\begin{array}{c}0.124 \\
(0.360)\end{array}$ & $\begin{array}{l}-0.843^{*} \\
(0.476)\end{array}$ & & \\
\hline High-tech bidder & & & & $\begin{array}{c}0.932^{* * *} \\
(0.246)\end{array}$ & \\
\hline High-tech bidder $\times \%$ Intangibles talk & & & & $\begin{array}{l}-0.112 \\
(0.224)\end{array}$ & \\
\hline High IA industry & & & & & $\begin{array}{l}-0.889^{*} \\
(0.423)\end{array}$ \\
\hline High IA industry $\times \%$ Intangibles talk & & & & & $\begin{array}{l}0.448^{*} \\
(0.246)\end{array}$ \\
\hline Textual variables & Yes & Yes & Yes & Yes & Yes \\
\hline Controls & Yes & Yes & Yes & Yes & Yes \\
\hline Year FE & Yes & Yes & Yes & Yes & Yes \\
\hline Industry FE & Yes & Yes & Yes & No & No \\
\hline Adjusted $R^{2}$ & 0.05 & 0.06 & 0.05 & 0.04 & 0.04 \\
\hline Observations & 3036 & 1519 & 1517 & 3036 & 3036 \\
\hline
\end{tabular}




\section{Table 12: Robustness, part 1}

The table summarizes robustness checks for all main regressions. Panel A controls for disclosure quality as in Chen et al. (2015). Panel B controls for synergy words. Panel C controls for Intangibles talk in earnings conference calls. The sample consists of the takeovers announced between January 2002 and December 2016 with the bidder that is a publicly traded company domiciled in the United States. Column (1) presents probit regressions that estimate the propensity for the bidder to complete the deal following the takeover announcement. Column (2) reports OLS regression results for the number of days it takes to complete the deal, given that the bidder acquires the target. Column (3) reports OLS regression results for bidder cumulative abnormal returns, CAR(-1,1), measured using the Carhart four-factor model return. Column (4) reports OLS regression results for changes in ROA from year 0 to year 1, where year 0 is defined as the year of acquisition. We adjust bidder ROA changes by subtracting those of the bidder's industry peers. Column (5) reports results of probit regressions that estimate the propensity for the acquisition to be financed with cash. Finally, Column (6) reports results of probit regressions that estimate the propensity for the acquirer CEO to buy stock following the takeover announcement. For details, see the prior tables. \% Intangibles talk is defined as the number of intangibles words divided by the total number of words in the announcement, expressed as a percent. \% Synergy talk is defined as the number of synergies words (see the text) divided by the total number of words in the announcement, expressed as a percent. $\%$ Intangibles talk (conf.) is defined as the average, by firm, of the number of intangibles words divided by the total number of words in what management says in earnings conferences calls in the sample period, standardized to the same standard deviation as \% Intangibles talk. All regressions include industry and year fixed effects as well as the same firm-specific and deal-specific controls as before, as well as controls for negativity, uncertainty, and strong modal words in the announcement. Additional variable descriptions are provided in Table 2. The continuous dependent variables and continuous control variables are winsorized at the $1^{\text {st }}$ and $99^{\text {th }}$ percentiles. Regressions (1), (5) and (6) report average marginal effects instead of estimated coefficients. The standard errors (reported in parentheses) are clustered by the announcement year and are robust to heteroskedasticity. Significance levels: : * $-10 \%, * *-5 \%, * * *-1 \%$

(a) Panel A: Disclosure quality

\begin{tabular}{|c|c|c|c|c|c|c|}
\hline & $\begin{array}{c}(1) \\
\text { Completed }\end{array}$ & $\begin{array}{l}\text { Days to completion } \\
\text { Da }\end{array}$ & $\begin{array}{c}(3) \\
\operatorname{CAR}(-1,1)\end{array}$ & $\begin{array}{c}(4) \\
\Delta \operatorname{ROA}(0,1)\end{array}$ & $\begin{array}{c}(5) \\
\text { Cash pay }\end{array}$ & $\begin{array}{c}(6) \\
\text { CEO or Execs buy }\end{array}$ \\
\hline$\%$ Intangibles talk & $\begin{array}{c}0.017^{* * *} \\
(0.005)\end{array}$ & $\begin{array}{l}-3.198^{*} \\
(1.624)\end{array}$ & $\begin{array}{c}-0.451^{* * *} \\
(0.122)\end{array}$ & $\begin{array}{c}-0.438^{* *} \\
(0.194)\end{array}$ & $\begin{array}{c}0.041^{* * *} \\
(0.011)\end{array}$ & $\begin{array}{l}0.020^{* *} \\
(0.009)\end{array}$ \\
\hline Disclosure quality & $\begin{array}{l}-0.076 \\
(0.074)\end{array}$ & $\begin{array}{c}-2.934 \\
(17.071)\end{array}$ & $\begin{array}{c}0.429 \\
(3.260)\end{array}$ & $\begin{array}{l}-0.776 \\
(4.055)\end{array}$ & $\begin{array}{c}0.261 \\
(0.179)\end{array}$ & $\begin{array}{l}-0.151 \\
(0.108)\end{array}$ \\
\hline Adjusted $R^{2}$ & & 0.47 & 0.05 & 0.03 & & \\
\hline Pseudo $R^{2}$ & 0.30 & & & & 0.26 & 0.15 \\
\hline Observations & 3023 & 2801 & 3023 & 2319 & 3023 & 3023 \\
\hline
\end{tabular}

(b) Panel B: Synergy words

\begin{tabular}{|c|c|c|c|c|c|c|}
\hline & $\begin{array}{c}\text { (1) } \\
\text { Completed }\end{array}$ & $\begin{array}{c}\text { (2) } \\
\text { Days to completion }\end{array}$ & $\begin{array}{c}(3) \\
\text { CAR(-1,1) }\end{array}$ & $\begin{array}{c}(4) \\
\Delta \operatorname{ROA}(0,1)\end{array}$ & $\begin{array}{c}\text { (5) } \\
\text { Cash pay }\end{array}$ & $\begin{array}{c}\text { (6) } \\
\text { CEO or Execs buy }\end{array}$ \\
\hline$\%$ Intangibles talk & $\begin{array}{l}0.015^{* * *} \\
(0.005)\end{array}$ & $\begin{array}{l}-3.306^{*} \\
(1.667)\end{array}$ & $\begin{array}{c}-0.475^{* * *} \\
(0.141)\end{array}$ & $\begin{array}{l}-0.501^{* *} \\
(0.203)\end{array}$ & $\begin{array}{c}0.044^{* * *} \\
(0.010)\end{array}$ & $\begin{array}{l}0.019^{* *} \\
(0.009)\end{array}$ \\
\hline$\%$ Synergy talk & $\begin{array}{c}0.051^{* * *} \\
(0.015)\end{array}$ & $\begin{array}{c}1.315 \\
(4.816)\end{array}$ & $\begin{array}{c}0.488 \\
(0.762)\end{array}$ & $\begin{array}{l}1.474^{*} \\
(0.742)\end{array}$ & $\begin{array}{l}-0.049 \\
(0.030)\end{array}$ & $\begin{array}{c}0.002 \\
(0.020)\end{array}$ \\
\hline Adjusted $R^{2}$ & & 0.46 & 0.05 & 0.03 & & \\
\hline Pseudo $R^{2}$ & 0.31 & & & & 0.25 & 0.15 \\
\hline Observations & 3035 & 2813 & 3035 & 2328 & 3035 & 3035 \\
\hline
\end{tabular}

(c) Panel C: Intangibles talk on conference calls

\begin{tabular}{|c|c|c|c|c|c|c|}
\hline & $\begin{array}{c}(1) \\
\text { Completed }\end{array}$ & $\begin{array}{l}\text { (2) } \\
\text { Days to completion }\end{array}$ & $\begin{array}{c}(3) \\
\text { CAR(-1,1) }\end{array}$ & $\begin{array}{c}(4) \\
\Delta \operatorname{ROA}(0,1)\end{array}$ & $\begin{array}{c}\text { (5) } \\
\text { Cash pay }\end{array}$ & $\begin{array}{c}\text { (6) } \\
\text { CEO or Execs buy }\end{array}$ \\
\hline$\%$ Intangibles talk & $\begin{array}{c}0.017^{* * *} \\
(0.005)\end{array}$ & $\begin{array}{l}-2.994^{*} \\
(1.633)\end{array}$ & $\begin{array}{l}-0.308^{* *} \\
(0.142)\end{array}$ & $\begin{array}{l}-0.429^{*} \\
(0.200)\end{array}$ & $\begin{array}{c}0.040^{* * *} \\
(0.011)\end{array}$ & $\begin{array}{l}0.020^{* *} \\
(0.010)\end{array}$ \\
\hline$\%$ Intang. talk (conf.) & $\begin{array}{c}-0.002 \\
(0.006)\end{array}$ & $\begin{array}{l}-1.182 \\
(1.280)\end{array}$ & $\begin{array}{c}-0.649^{* * *} \\
(0.188)\end{array}$ & $\begin{array}{c}0.002 \\
(0.180)\end{array}$ & $\begin{array}{c}0.010 \\
(0.008)\end{array}$ & $\begin{array}{l}-0.005 \\
(0.009)\end{array}$ \\
\hline Adjusted $R^{2}$ & & 0.46 & $53 \quad 0.05$ & 0.03 & & \\
\hline Pseudo $R^{2}$ & 0.30 & & & & 0.25 & 0.15 \\
\hline Observations & 3035 & 2813 & 3035 & 2328 & 3035 & 3035 \\
\hline
\end{tabular}




\section{Table 13: Robustness, part 2}

The table summarizes robustness checks for all main regressions. Panel A controls for managerial ability (in percentile ranks by industry and year) as in Demerjian et al. (2012). Panel B uses industry-year fixed effects. Panel C omits deals with the smallest $1 \%$ and largest $1 \%$ of deal volumes. The sample consists of the takeovers announced between January 2002 and December 2016 with the bidder that is a publicly traded company domiciled in the United States. Column (1) presents probit regressions that estimate the propensity for the bidder to complete the deal following the takeover announcement. Column (2) reports OLS regression results for the number of days it takes to complete the deal, given that the bidder acquires the target. Column (3) reports OLS regression results for bidder cumulative abnormal returns, CAR(-1,1), measured using the Carhart four-factor model return. Column (4) reports OLS regression results for changes in ROA from year 0 to year 1, where year 0 is defined as the year of acquisition. We adjust bidder ROA changes by subtracting those of the bidder's industry peers. Column (5) reports results of probit regressions that estimate the propensity for the acquisition to be financed with cash. Finally, Column (6) reports results of probit regressions that estimate the propensity for the acquirer CEO to buy stock following the takeover announcement. For details, see the prior tables. \% Intangibles talk is defined as the number of intangibles words divided by the total number of words in the announcement, expressed as a percent. All regressions include industry and year fixed effects as well as the same firm-specific and deal-specific controls as before, as well as controls for negativity, uncertainty, and strong modal words in the announcement. Additional variable descriptions are provided in Table 2 . The continuous dependent variables and continuous control variables are winsorized at the $1^{\text {st }}$ and $99^{\text {th }}$ percentiles. Regressions (1), (5) and (6) report average marginal effects instead of estimated coefficients. The standard errors (reported in parentheses) are clustered by the announcement year and are robust to heteroskedasticity. Significance levels: : * - 10\%, ** - 5\%, ***-1\%

(a) Panel A: Managerial ability

\begin{tabular}{lcccccc}
\hline & $\begin{array}{c}(1) \\
\text { Completed }\end{array}$ & $\begin{array}{c}(2) \\
\text { Days to completion }\end{array}$ & $\begin{array}{c}(3) \\
\text { CAR(-1,1) }\end{array}$ & $\begin{array}{c}(4) \\
\Delta \mathrm{ROA}(0,1)\end{array}$ & $\begin{array}{c}(5) \\
\text { Cash pay }\end{array}$ & $\begin{array}{c}(6) \\
\text { CEO or Execs buy }\end{array}$ \\
\hline \% Intangibles talk & $0.019^{* * *}$ & -2.217 & $-0.499^{* * *}$ & -0.391 & $0.043^{* * *}$ & $0.018^{*}$ \\
& $(0.005)$ & $(1.626)$ & $(0.144)$ & $(0.226)$ & $(0.010)$ & $(0.010)$ \\
Managerial ability & -0.026 & 4.681 & -0.953 & 0.509 & -0.109 & $-0.136^{* * *}$ \\
& $(0.027)$ & $(6.928)$ & $(1.113)$ & $(1.373)$ & $(0.102)$ & $(0.041)$ \\
\hline Adjusted $R^{2}$ & & 0.47 & 0.05 & 0.05 & & \\
Pseudo $R^{2}$ & 0.32 & & & & 0.25 & 0.16 \\
Observations & 2847 & 2652 & 2847 & 2248 & 2847 & 2847 \\
\hline
\end{tabular}

(b) Panel B: Industry-year fixed effects

\begin{tabular}{lcccccc}
\hline & $\begin{array}{c}(1) \\
\text { Completed }\end{array}$ & $\begin{array}{c}(2) \\
\text { Days to completion }\end{array}$ & $\begin{array}{c}(3) \\
\text { CAR }(-1,1)\end{array}$ & $\begin{array}{c}(4) \\
\Delta \text { ROA }(0,1)\end{array}$ & $\begin{array}{c}(5) \\
\text { Cash pay }\end{array}$ & $\begin{array}{c}\text { (6) } \\
\text { CEO or Execs buy }\end{array}$ \\
\hline \% Intangibles talk & $0.014^{* *}$ & $-2.667^{* *}$ & $-0.529^{* * *}$ & -0.310 & $0.037^{* * *}$ & $0.018^{* *}$ \\
& $(0.006)$ & $(1.341)$ & $(0.188)$ & $(0.345)$ & $(0.011)$ & $(0.009)$ \\
$\left(\mathrm{IA} \mathrm{PT}_{\mathrm{PT}} / \mathrm{AT}\right)_{\mathrm{b}}$ & 0.005 & $-7.232^{* *}$ & -0.271 & 0.073 & $-0.055^{* * *}$ & $0.026^{*}$ \\
& $(0.008)$ & $(2.829)$ & $(0.574)$ & $(0.761)$ & $(0.018)$ & $(0.014)$ \\
Industry-Year FE & Yes & Yes & Yes & Yes & Yes & Yes \\
\hline Adjusted $R^{2}$ & & 0.50 & 0.04 & 0.04 & & 0.38 \\
Pseudo $R^{2}$ & 0.47 & 2813 & 3035 & 2328 & 3035 & 3035 \\
Observations & 3035 & & & & & \\
\hline
\end{tabular}

(c) Panel C: Omitting very small and very large deals

\begin{tabular}{lcccccc}
\hline & $\begin{array}{c}(1) \\
\text { Completed }\end{array}$ & $\begin{array}{c}(2) \\
\text { Days to completion }\end{array}$ & $\begin{array}{c}(3) \\
\mathrm{CAR}(-1,1)\end{array}$ & $\begin{array}{c}(4) \\
\Delta \mathrm{ROA}(0,1)\end{array}$ & $\begin{array}{c}(5) \\
\text { Cash pay }\end{array}$ & $\begin{array}{c}(6) \\
\text { CEO or Execs buy }\end{array}$ \\
\hline \% Intangibles talk & $\begin{array}{c}0.016^{* * *} \\
(0.005)\end{array}$ & $\begin{array}{c}-3.151^{*} \\
(1.595)\end{array}$ & $\begin{array}{c}-0.456^{* * *} \\
(0.129)\end{array}$ & $\begin{array}{c}-0.431^{*} \\
(0.205)\end{array}$ & $\begin{array}{c}0.042^{* * *} \\
(0.011)\end{array}$ & $\begin{array}{c}0.019^{*} \\
(0.010)\end{array}$ \\
\hline Adjusted $R^{2}$ & & 0.45 & 0.05 & 0.03 & & \\
$\begin{array}{l}\text { Pseudo } R^{2} \\
\text { Observations }\end{array}$ & 0.29 & 2796 & 3005 & 2316 & 3005 & 0.15 \\
\hline
\end{tabular}




\section{Supplementary Appendix}

\section{A Sample construction}

\section{Table SA.1: Sample construction}

This table lists the steps taken to form the sample of M\&A deals announced between 2002 and 2016 that are available in the SDC database.

\begin{tabular}{lr}
\hline Sample filters & \# of deals \\
\hline Date announced: January 1, 2002 to December 31, 2016 & 662,428 \\
Bidder is a US company & 160,511 \\
Bidder is a public company & 64,903 \\
Exclude: recapitalizations, repurchases, self-tenders and exchange offers & 54,102 \\
Deal value ( $\$$ mil) $\geq 1$ & 24,538 \\
$\%$ of shares held at announcement $\leq 15 \%$ & 23,504 \\
$\%$ of shares owned after transaction $\geq 80 \%$ (only for completed deals) & 21,993 \\
Target is a private or public company & 14,484 \\
Payment method: cash, stock or a mix of cash and stock & 11,099 \\
Exclude bidders that operate in regulated utilities (SIC code 4900-4999) & \\
or in the financial industry (SIC code 6000-6999) & 8,207 \\
Return data on CRSP & 5,866 \\
Accounting data on Compustat & 5,605 \\
Relative size $\geq 1 \%$ & 4,794 \\
Acquirer book value of equity positive & 4,682 \\
Acquirer files an 8-K within 4 business days after the announcement & 3,730 \\
M\&A announcement identified & 3,060 \\
Peters and Taylor (2017) measure of intangible assets for bidder & 3,036 \\
\hline
\end{tabular}




\section{B Target intangible assets}

\section{Table SA.2: Correlation of the measures of target intangible assets}

The table reports the correlation coefficients for three different measures of target intangible assets that are used in the analysis. Panel A reports the correlation between the measures of absolute size of target intangible assets while panel B presents the correlation between the ratios of intangible assets to target total assets size. Intan. assets $_{b}$ is the book value of target intangible assets. Intan. assets $a c q$ is the estimate of acquired target intangible assets calculated as the difference between deal size and the book value of target tangible assets. Intan. assets at $_{P T}$ is the estimated replacement cost of target's intangible capital (introduced in Peters and Taylor (2017) and available in WRDS). IA/AT is the ratio of target intangible assets (IA) to the book value of target total assets (AT).

(a) Panel A: Absolute size

\begin{tabular}{|c|c|c|c|}
\hline & $\left(\text { Intan. assets }{ }_{b v}\right)_{t}$ & $\left(\text { Intan. } \text { assets }_{\text {acq }}\right)_{\mathrm{t}}$ & $\left(\text { Intan. assets }{ }_{\mathrm{PT}}\right)_{\mathrm{t}}$ \\
\hline$\left(\text { Intan. } \text { assets }_{\text {bv }}\right)_{t}$ & 1 & & \\
\hline$\left(\text { Intan. assets } \mathrm{acc}_{\mathrm{c}}\right)_{\mathrm{t}}$ & $0.594^{* * *}$ & 1 & \\
\hline$\left(\text { Intan. assets }{ }_{\mathrm{PT}}\right)_{\mathrm{t}}$ & $0.833^{* * *}$ & $0.678^{* * *}$ & 1 \\
\hline
\end{tabular}

(b) Panel A: Size relative to total assets

\begin{tabular}{cccc}
\hline & $\left(\mathrm{IA}_{\mathrm{bv}} / \mathrm{AT}\right)_{\mathrm{t}}$ & $\left(\mathrm{IA} \mathrm{acq}_{\mathrm{acq}} / \mathrm{AT}\right)_{\mathrm{t}}$ & $\left(\mathrm{IA}_{\mathrm{PT}} / \mathrm{AT}\right)_{\mathrm{t}}$ \\
\hline$\left(\mathrm{IA} \mathrm{bv}_{\mathrm{bv}} / \mathrm{AT}\right)_{\mathrm{t}}$ & 1 & & \\
$\left(\mathrm{IA} \mathrm{acq}_{\mathrm{acq}} / \mathrm{AT}\right)_{\mathrm{t}}$ & -0.026 & 1 & 1 \\
$\left(\mathrm{IA} \mathrm{PTT}_{\mathrm{PT}} / \mathrm{AT}\right)_{\mathrm{t}}$ & 0.0014 & $0.10^{* * *}$ & 1 \\
\hline
\end{tabular}




\section{Combined announcement returns}

\section{Table SA.3: Combined announcement returns for public targets}

The table reports regression results for bidder, target and combined cumulative abnormal returns, CAR(-1,1), measured using Carhart four-factor model return. Combined CAR is calculated as a value weighted average of the bidder and target CAR(-1,1) where weights are calculated as day 0 market value of equity. The sample consists of public-target takeover announcements between January 2002 and December 2016 with the bidder that is a publicly traded company domiciled in the United States. The number of observations in columns (3) to (6) is smaller than in columns (1) and (2) because we do not have CAR data for targets abroad. \% Intangibles talk is defined as the number of intangibles words divided by the total number of words in the announcement, expressed as a percent. The regressions control for the same variables as Table 6. Additional variable descriptions are provided in Table 2. The dependent variables and continuous control variables are winsorized at the $1^{\text {st }}$ and $99^{\text {th }}$ percentiles. The standard errors (reported in parentheses) are clustered by the announcement year and are robust to heteroskedasticity. Significance levels: : *-10\%,**-5\%,***-1\%

\begin{tabular}{|c|c|c|c|c|c|c|}
\hline & \multicolumn{2}{|c|}{ Bidder CAR } & \multicolumn{2}{|c|}{ Target CAR } & \multicolumn{2}{|c|}{ Combined CAR } \\
\hline & (1) & (2) & (3) & (4) & (5) & (6) \\
\hline$\%$ Intangibles talk & $\begin{array}{c}-1.604^{* * *} \\
(0.451)\end{array}$ & $\begin{array}{c}-1.596^{* * *} \\
(0.491)\end{array}$ & $\begin{array}{c}0.678 \\
(2.200)\end{array}$ & $\begin{array}{c}0.451 \\
(2.469)\end{array}$ & $\begin{array}{c}-1.008 \\
(0.598)\end{array}$ & $\begin{array}{l}-0.982 \\
(0.743)\end{array}$ \\
\hline Negativity & & $\begin{array}{l}-0.939 \\
(0.857)\end{array}$ & & $\begin{array}{l}-0.367 \\
(5.385)\end{array}$ & & $\begin{array}{c}-1.444 \\
(1.852)\end{array}$ \\
\hline$\%$ Uncertainty & & $\begin{array}{c}2.950^{*} \\
(1.452)\end{array}$ & & $\begin{array}{l}-2.498 \\
(6.104)\end{array}$ & & $\begin{array}{c}2.397 \\
(1.709)\end{array}$ \\
\hline$\%$ Strong modal & & $\begin{array}{c}-0.004 \\
(2.805)\end{array}$ & & $\begin{array}{c}-3.837 \\
(12.664)\end{array}$ & & $\begin{array}{c}0.556 \\
(3.606)\end{array}$ \\
\hline Controls & Yes & Yes & Yes & Yes & Yes & Yes \\
\hline Year FE & Yes & Yes & Yes & Yes & Yes & Yes \\
\hline Industry FE & Yes & Yes & Yes & Yes & Yes & Yes \\
\hline Adjusted $R^{2}$ & 0.14 & 0.14 & 0.10 & 0.10 & 0.17 & 0.17 \\
\hline Observations & 913 & 913 & 634 & 634 & 634 & 634 \\
\hline
\end{tabular}

\section{Data appendix}

\section{D.1 8-K download and identification}

The download procedure starts with quarterly master index files from EDGAR. The indexes can be found at the following location: https://www.sec.gov/Archives/edgar/full-index/ [year] /QTR [1-4] /master .zip, and have entries in this form: CIK / CompanyName | FormType | DateFiled|Filename. ${ }^{31}$ The indexes contain the whole universe of filings. We loop through them and look for the CIK codes from our takeover sample that are associated with the 8-K form type, and are filed no later than 4 business days after the announcement date. ${ }^{32} \mathrm{We}$ allow for filings that are made one business day before the announcement date reported by SDC

\footnotetext{
${ }^{31}$ For example, the first quarter master index file in 2007 is located here: https://www.sec.gov/Archives/edgar/full-index/2007/QTR1/master.zip and one of its entries is: 1004155 | AGLRESOURCESINC | 10-K | 2007-02-07 | edgar/data/1004155/0001004155-07-000038.txt

${ }^{32}$ We construct a business day calendar by downloading the S\&P 500 index from CRSP and keeping only trading dates from the set.
} 
due to inconsistencies across EDGAR and SDC (see Section D.2). Some companies file multiple 8-Ks within 4-day period after the announcement, which requires additional verification checks.

When companies file with the SEC they rarely submit only one document. EDGAR takes all filing documents, processes them, and then bunches those together into a single text file. A typical 8-K filing has a SEC header and one or more documents that follow. There is no announcement date nor announcement time specified in the header. The acceptance time field is missing in some filings. Acquisition announcements are saved in one of the documents that follow the header. The documents can be either in text, html or $p d f$ format. Each one starts with the $<$ DOCUMENT $>$ tag that is followed by a number of document header fields after which comes the actual content bounded by the $\langle$ TEXT $>$ and $\langle/$ TEXT $\rangle$ tags. The documents end with the </DOCUMENT $>$ tag. The document header contains a type, a sequence number, filename and the document description. Press releases of acquisition announcements are saved in the documents that are labelled as Exhibit 99, Exhibit 99.1, Exhibit 99.2, etc. There is no document type or attachment number that uniquely identifies acquisition filings or acquisition announcement press releases. We parse all filings and identify the documents we need based on their content.

First, we split 8-K files into documents using document tags, <DOCUMENT $>$ and </DOCUMENT $>$. The text files extracted from an 8 -K filing are already in the format that can be used in the further analysis, while both html and pdf files need some additional processing before we can get any useful text from them. Html files have a lot of overhead in the form of html tags that carry no announcement information, but rather give structure to unstructured text. Pdf files have no overhead, but are in the binary format. We use Apache Tika to clean documents that are in the html or pdf format. This procedure works immediately with html documents. It fails when applied directly to pdf files extracted and saved in the form they are found in 8-K text files. The procedure does not work because pdf files are encoded using uuencoding, a form of binary-to-text encoding, before they are put into the 8-K text files. Therefore, we first decode pdf files, that is translate them from text to the binary format, and then we apply Tika methods on the decoded pdf files. This yields clean text that can be used for announcement detection and further textual analysis.

The next task is the most challenging one, the announcement identification itself. We read and analyze dozens of the documents that we have extracted from $8-\mathrm{K}$ files. We then develop a procedure that aims to replicate our own reasoning behind the conclusion we make when facing a problem to identify announcements, and minimize the number of the documents wrongly labeled as potential announcements. We find that a typical announcement press release document has a title section that is followed by an announcement body. The title section can be very short and contain only the title itself, but there are cases when it is rather long with many bullet points and additional information. The announcement body typically starts with Place + Date + Acquirer + Acquirer Ticker, "the body start" hereafter. Yet there is some variation. For example, any of these 4 elements might be missing: date is referenced using "today", a year is missing, the date comes before the place, or the acquirer and its ticker might not be mentioned immediately after the date. Section D.3 provides an example.

We split the announcement identification procedure in 2 steps. The first and more restrictive step relies on the analysis of the beginning of the document only. The second step applies less restrictive requirements on the set of deals that have no announcement document 
found after the first step. Put differently, the second step checks the deals with no announcement found and picks the related documents that did not meet more restrictive criteria checked in the first step.

The first step starts with requirements that a document:

- is an Exhibit 99 document,

- is neither defined as a conference call nor financial results release in the description field,

- does not contain conference call speech words, e.g. good day, dear etc. (see Section D.5 for the full list), which are typically not used in acquisition announcements, and

- contains words that indicate purchase (acquire, purchase, merge etc., see Section D.5).

A document is Exhibit 99 if its type field starts with ex-99, ex99 or ex 99, case-insensitive (for example <TYPE $>$ EX-99.1). We identify the body start in any of its possible forms mentioned earlier. We exploit regular expressions for that task. If the body start is not detected within the first 300 words, we disregard the document. If we find the body start, we then inspect text before it, which is in fact the title section. If the title section contains no purchase words nor the target name, but it contains the conference call (which are not the same as conference call speech words), financial results, or public or tender offer words, we disregard the document. Next, we check text that follows the body start. This is the point in text that usually clearly specifies what the document talks about. A topic is usually clearly stated in the first paragraph. We inspect 150 words that follow the body start and require that both purchase words and the target name is detected. If a document passes all these checks, we label it as a potential announcement. We say potential because there can be more than one document that passes all checks. The requirements listed do not necessarily uniquely identify documents that are acquisition announcements. For example, an 8-K filing may, despite not being an acquisition announcement, mention the target and meet the rest of criteria (e.g. quarterly earnings announcement, conference call transcripts, a presentation of the deal, etc.), or when an amendment $(8-\mathrm{K} / \mathrm{A})$ is issued following the announcement $(8-\mathrm{K}) .{ }^{33}$ Even though we observe multiple documents, only one, in fact, is the announcement itself.

The second step helps identify deal announcements that the first step fails to find. A drawback is that it occasionally labels multiple documents as announcements what requires manual inspection. However, the number of such cases is rather small as the first step already did a good job for the major part of the deals. The second step is simpler than the first one. It does not distinguish between the title section and announcement body, but relies simply on the set of requirements that the full document has to meet in order to qualify as a potential acquisition announcement. In addition to the content-based filters listed below, we require that the minimum word count is more than 30 words and less than 5,000. in terms of content, we require that a document:

- is an Exhibit 99 document,

- is neither indicated as a conference call nor a financial results release in the description field,

- mentions the target name,

- contains words that indicate purchase (acquire, purchase, merge etc.), as in Section D.5

\footnotetext{
${ }^{33}$ We have also found cases of a company filing the same announcement two times within the same day (e.g. CIK: 0000880460; "December 23, 2011 - Perfumania Holdings, Inc. (NASDAQ:PERF) and Parlux Fragrances, Inc. (NASDAQ:PARL) announced today that they have signed a definitive merger agreement...")
} 
- contains announcement words either in the document description field or text (press release, acquisition announcement etc.), and

- contains a "forward-looking statement" disclosure.

SDC does not always record target names in the form they appear in the announcements: short names are used, words such as Inc., Corp., etc. might be omitted, subsidiaries are described if they do not have a name etc. For these reasons we use a fuzzy search procedure (Section D.4). ${ }^{34}$ We require that the fuzzy match score is at least $70 \%$ in order to confirm that the target name is found in the document.Forward looking statement is something that we observe in all announcements checked, hence we include it in the list of requirements.

\section{D.2 SDC and EDGAR inconsistencies}

There are some inconsistencies regarding announcement dates between SDC and EDGAR. In order to include cases like the one shown below, we have to allow for announcements made 1 business day before the announcement date in SDC.

Example:

SDC Deal Number: 2167136040

SDC Announcement date: 2010/03/24

SEC Filing Date: 2010-03-23

SEC 8K announcement text:

"ROGERS, Conn.-(BUSINESS WIRE)-March 23, 2010-Rogers Corporation (NYSE: $R O G)$ announced today that it has signed an agreement with SK Chemicals Co. Ltd. of South Korea, to acquire SK Utis Co., Ltd., its high performance polyurethane foam manufacturing unit located in Ansan, South Korea..."

${ }^{34}$ Packages that implement fuzzy search algorithms are readily available in Java. We use FuzzyWuzzy library. 


\section{D.3 Typical acquisition Announcement structure}

A typical announcement press release document has a title section that is followed by an announcement body. The title section can be very short and contain only the title, but there are cases when it is rather long with many bullet points and additional information. The announcement body typically starts with this structure: Place + Date + Acquirer + Acquirer Ticker (Figure SA.1). Yet there is some variation. For example, any of this 4 elements might be missing, the date may be referenced using "today", the year may be missing, the date may come before the place, or acquirer and its ticker might be mentioned not immediately after the date.

NEWS RELEASE

FOR IMMEDIATE RELEASE

Title section

Telephone and Data

Systems Agrees to Acquire BendBroadband

Supports Cable and

Broadband Growth Strategy

CHICAGO, Ill., (May 1, 2014) - Telephone and Data

Systems, Inc. [NYSE: TDS], parent company to TDS

Telecom, today announced an agreement to acquire

substantially all of the assets of a group of

Announcement body

companies operating as BendBroadband, headquartered in

Bend, Oregon, for a purchase price of $\$ 261$ million

...

Figure SA.1: Typical announcement press release

\section{D.4 Target name detection (fuzzy matching)}

Example:

1. SDC deal number: 2012952020

SDC target name: Pernod Ricard SA-Cruzan Rum

8K: 0001193125-08-189343

$8 \mathrm{~K}$ announcement text:

"Under the agreement, Pernod Ricard will pay Fortune Brands $\$ 230$ million in pre-tax proceeds, and Fortune Brands will pay $\$ 100$ million to Pernod to acquire the premium Cruzan Rum brand..."

2. SDC deal number: 1313490020 
SDC target name: Smurfit-Stone-Industrial Pkg

8K: 0000950144-02-007750

$8 \mathrm{~K}$ announcement text:

"Caraustar Industries, Inc. (NASDAQ-NMS Symbol: CSAR) today announced that it has entered into a definitive agreement with a subsidiary of Smurfit-Stone Container Corporation (NASDAQ:SSCC) to acquire substantially all the assets (excluding accounts receivable) of Smurfit's Industrial Packaging Group business for a purchase price of approximately $\$ 79.8$ million..."

3. SDC target name: Frank's Tubular Intl Inc

$8 \mathrm{~K}$ announcement text:

"Dallas, TX, May 29, 2003-Lone Star Technologies, Inc. ("Lone Star”) (NYSE:LSS) today announced that it has signed a definitive agreement to acquire the assets of Frank's Tubular International ("FTI"), a Houston-based provider of high-quality threading and inspection services, ...” 


\section{D.5 Word lists used in the 8-K parsing}

\begin{tabular}{|c|c|c|c|c|c|c|c|c|}
\hline Purchase & Announcement & Financial Results & Public or Tender Offer & Conference Call & Completion & Acquisition & Months & ConfCall Speech \\
\hline $\begin{array}{l}\text { acquire } \\
\text { acquires } \\
\text { acquiring } \\
\text { acquired } \\
\text { acquisition } \\
\text { acquisitions } \\
\text { purchase } \\
\text { purchases } \\
\text { purchasing } \\
\text { purchased } \\
\text { buy } \\
\text { buys } \\
\text { buying } \\
\text { bought } \\
\text { merge } \\
\text { merges } \\
\text { merging } \\
\text { merged } \\
\text { merger } \\
\text { mergers } \\
\text { definite agreement } \\
\text { definite agreements } \\
\text { expand } \\
\text { expands } \\
\text { expanding } \\
\text { expanded } \\
\text { expansion }\end{array}$ & $\begin{array}{l}\text { press release } \\
\text { news release } \\
\text { press announcement } \\
\text { news announcement } \\
\text { acquisition announcement } \\
\text { merger announcement } \\
\text { purchase announcement } \\
\text { immediate release }\end{array}$ & $\begin{array}{l}\text { quarter } \\
\text { quarters } \\
\text { full year } \\
\text { full-year } \\
\text { fiscal year } \\
\text { results } \\
\text { earnings } \\
\text { net income } \\
\text { revenue } \\
\text { revenues } \\
\text { financial guidance }\end{array}$ & $\begin{array}{l}\text { public offer } \\
\text { tender offer } \\
\text { stock offer } \\
\text { private placement } \\
\text { offering } \\
\text { issue } \\
\text { issues } \\
\text { issuing } \\
\text { issued } \\
\text { issuance }\end{array}$ & $\begin{array}{l}\text { conference call } \\
\text { transcript } \\
\text { script }\end{array}$ & $\begin{array}{l}\text { close } \\
\text { closes } \\
\text { closed } \\
\text { closing } \\
\text { complete } \\
\text { completes } \\
\text { completed } \\
\text { completing } \\
\text { completion }\end{array}$ & $\begin{array}{l}\text { acquisition } \\
\text { merger } \\
\text { purchase }\end{array}$ & $\begin{array}{l}\text { Jan. } \\
\text { Feb. } \\
\text { Mar. } \\
\text { Apr. } \\
\text { Jun. } \\
\text { Jul. } \\
\text { Aug. } \\
\text { Sep. } \\
\text { Oct. } \\
\text { Nov. } \\
\text { Dec. } \\
\text { January } \\
\text { February } \\
\text { March } \\
\text { April } \\
\text { May } \\
\text { June } \\
\text { July } \\
\text { August } \\
\text { September } \\
\text { October } \\
\text { November } \\
\text { December }\end{array}$ & $\begin{array}{l}\text { good morning } \\
\text { good day } \\
\text { good afternoon } \\
\text { good evening } \\
\text { hello } \\
\text { hi } \\
\text { dear } \\
\text { ladies and gentlemen }\end{array}$ \\
\hline
\end{tabular}

